University of Wollongong

Research Online

Faculty of Business - Papers (Archive)

Faculty of Business and Law

2018

Political promotion, CEO incentives, and the relationship between pay and performance

Xiaping Cao

Sun Yat-Sen University

Michael Lemmon

Xiaofei Pan

University of Wollongong, xpan@uow.edu.au

Meijun Qian

Australian National University

Gary G. Tian

Macquarie University, gtian@uow.edu.au

Follow this and additional works at: https://ro.uow.edu.au/buspapers

Part of the Business Commons

Research Online is the open access institutional repository for the University of Wollongong. For further information contact the UOW Library: research-pubs@uow.edu.au 


\title{
Political promotion, CEO incentives, and the relationship between pay and performance
}

\begin{abstract}
Both theory and empirical evidence suggest that managers' career concerns can serve as an important source of implicit economic incentives. We examine how incentives for political promotion are related to compensation policy and firm performance in Chinese state-owned enterprises. We find that the likelihood that the CEO receives a political promotion is positively related to firm performance. We also find that CEOs with a higher likelihood of political promotion have lower pay levels and lower payperformance sensitivity. Overall, the evidence suggests that competition in the political job market helps mitigate weak monetary incentives for CEOs in China.
\end{abstract}

\section{Keywords}

promotion, political, between, relationship, performance, incentives, pay, ceo

\section{Disciplines \\ Business}

\section{Publication Details}

Cao, X., Lemmon, M., Pan, X., Qian, M. \& Tian, G. (2019). Political promotion, CEO incentives, and the relationship between pay and performance.Management Science, 65 (7), 2947-3448. 


\title{
Political Promotions, CEO Incentives, and the Relationship between Pay and Performance
}

\begin{abstract}
Both theory and empirical evidence suggest that managers' career concerns can serve as an important source of implicit economic incentives. We examine how incentives for political promotion are related to compensation policy and firm performance in Chinese state-owned enterprises (SOEs). We find that the likelihood that the CEO receives a political promotion is positively related to firm performance. We also find that CEOs with a higher likelihood of political promotion have lower pay levels and lower pay-for-performance sensitivity. Overall, the evidence suggests that competition in the political job market helps mitigate weak monetary incentives for CEOs in China.
\end{abstract}

Keywords: Managerial incentives, political promotion, performance, CEO compensation

JEL: G30 G32 G34 


\section{Introduction}

A number of papers argue that managers' career concerns provide implicit incentives for managerial effort (Fama, 1980; Holmstrom, 1999) and may even substitute for explicit incentives in their compensation contracts. For example, Gibbons and Murphy (1992) provide a model and some supporting empirical evidence in which the pay-performance sensitivity should rise as CEOs approach retirement in order to continue to provide incentives for effort. Alternatively, Brickley, Coles, and Linck (1999) show that career concerns of CEOs in the US do not end at retirement as many retired CEOs continue to serve as board members following retirement and that these postretirement employment opportunities are associated with the firm's performance in their last years as CEOs. Moreover, Coles, Li, and Wang (2012) show that moving to larger firms with higher compensation also provide CEOs with career incentives: firm performance is positively associated with the pay gap between the firm' CEO and the top paid CEOs in the same industry. Therefore, as pay-performance should rise as CEOs near retirement to provide incentives, correspondingly pay-performance could be lower for CEOs who have stronger career incentives. However, empirical evidence on the latter substitution effect between career incentives and monetary incentives are limited. ${ }^{1}$

Our paper fills this gap by examining how pay-performance sensitivity for CEOs is affected by external career tournaments. We exploit features associated with State Owned Enterprises

\footnotetext{
${ }^{1}$ Empirical evidence on CEO career concern in USA is limited because CEOs are at the top of corporate ladder. Therefore, empirical evidence on career concern are mostly based on internal promotion such as promoting senior managers to higher positions. Lazear and Rosen (1981) argue that senior managers at the lower level have strong incentive to compete for promotion to the higher level. As only those with the highest ability could succeed, senior managers with higher career incentives are willing to take more costly and risky actions to maximize their output and enlarge their promotion probability (Kini and Williams 2012). Such career concerns appear larger in the managers' earlier career stages (Kale, Reis and Venkateswaran 2009). Cichello, Fee, Hadlock, and Sonti (2009) study turnover and promotions of division managers in multidivisional firms. They find that, consistent with tournament theory, promotions are significantly related to whether one division is performing better than others and that accounting information is used by firms when evaluating managerial personnel.
} 
(SOEs) in China, to provide new evidence on the interactions between career concerns and compensation policy and their effects on managerial behavior. In China, the State is often (directly or indirectly) the largest shareholder and the government retains ultimate control of personnel in the corporate sector, including the right to appoint the CEO. ${ }^{2}$ Therefore, different from US where there is an active external managerial labor market, CEOs in China's SOEs are more concerned about assessment by government officials than with options in the managerial labor market, providing managers with strong incentives to increase their probability of political promotion, an upward move from a managerial position to a political position either in the firm or in the government (Groves, Hong, Mcmillan, and Naughton 1995; Li and Zhou 2005 etc). ${ }^{3}$

Chinese government values strong economic performance as an important factor in the political promotion process: $\mathrm{Li}$ (1998) notes that starting in the early 1980s, the central government mandated that bureaucrats at various levels be familiar with capitalist ideas and the current SOE managerial promotion guidelines explicitly include firm performance in the CEO evaluation matrix. ${ }^{4}$ Qian and Xu (1993) and Li and Zhou (2005) find a significantly positive correlation between the change in a region's economic performance and a change in its political position. These government documents and evidence on provincial leader promotion suggest that political promotion of a CEO will be likely positively associated with firm performance during the manager's tenure.

\footnotetext{
${ }^{2}$ In 2006, SOEs accounted for more than 30\% of the China's GDP and approximately $90 \%$ of all publicly listed firms. SOEs play a central role in pivotal industries such as energy, steel, machinery and national defence ( $\mathrm{Li}$ and Putterman, 2008). The public sector is often dominated by large SOEs, which provide key inputs to facilitate private sector growth and investment, and are regarded as a foundation of national growth.

${ }^{3}$ Over our sample period only 2 promotions correspond to CEOs in SOEs departing for jobs in privately run firms.

${ }^{4}$ The Guidelines for Performance Evaluation of CEOs of Central State Owned Enterprises is available online at http://www.sasac.gov.cn/n1180/n1566/n257060/n257203/1705038.html. According to these guidelines, the annual performance indicator is ROA = profit/assets (Item 8-2), the indicator for performance over a CEO's tenure is the \% change in (total assets-total liability) over the period (Item15-1), and the 3-year performance indicator is (sales growth over past 3 years) ${ }^{\wedge}(1 / 3)$ (Item $\left.15-2\right)$.
} 
Whether political promotion provides significant managerial incentive is particularly important for Chinese SOEs given the insufficient monetary incentives in their compensation policy. Groves et al. (1995) show that managerial pay began to exhibit a stronger link to profits and a weaker link to sales following the initial reforms of Chinese SOEs undertaken by the government in the 1980's. Consistent with the predictions of agency theory, Mengistae and Xu (2004) find that the sensitivity of CEO compensation to performance is decreasing in the variance of performance measures and increasing in the marginal return to executive effort. Firth et al. (2006a) further find that pay responds positively to performance in Chinese SOEs, but argue that the implied pay-performance sensitivities are too low to provide meaningful incentives.

Our research questions are twofold. First, is political promotion of CEOs based on economic factors? This question concerns whether political career incentives are consistent with shareholders' interests. Second, how does the political promotion motive interact with compensation incentives to affect managerial behavior? To answer the first question, we start with the government's explicit guidelines on evaluating and promoting CEOs in SOEs and add supporting empirical analysis.

To answer the second question, we examine how CEO pay and pay-performance sensitivity vary depending on the CEOs' likelihood of achieving a political promotion. The career concern theory (Gibbons and Murphy, 1992) suggests that CEOs' rewards for efforts come from two sources: one is the monetary rewards from the current job and the other is the career rewards beyond the current job. As such, two incentive components motivate managerial effort together, making it possibly incentive-compatible to obtain high effort even while one of the incentive constraints is slack. In our setting, we expect political promotion incentives to substitute for monetary incentive. ${ }^{5}$ That is, we expect that CEOs with a high likelihood of political promotion

\footnotetext{
${ }^{5}$ Another interpretation of the career concern is as follows: when the prior about the agent's quality is more diffuse (e.g., CEOs are young), performance becomes a more important signal. The agent therefore works harder due to the
} 
receive less pay and their pay is less sensitive to firm performance compared to CEOs with a low likelihood of political promotion.

Controlling for endogeneity to the best of our ability, we find that the likelihood of CEOs in Chinese SOEs receiving a political promotion is positively related to firm performance in both the government guidelines and the empirical data, which suggests that political incentives are not always misaligned with value maximization. We also find that the positive relationship between pay and firm performance weakens when a CEO has a higher likelihood of receiving a political promotion. This finding is consistent with the idea that incentives for political promotion substitute for explicit compensation incentives, as predicted by models of career concerns (Gibbons and Murphy, 1992; Brickley et al., 1999).

Endogeneity, omitted variables, and reverse causality are important concerns and we address each of them in our analysis. While CEO pay depends on the CEO's prospect of political promotion and some firm and CEO characteristics, political promotion itself is also determined by a set of firm and CEO characteristics. To control for this endogeneity issue, we employ a two-stage least square (2SLS) approach, augmented from the conventional procedure because political promotion is a discrete outcome. First, we analyze determinants of political promotion with firm characteristics, CEO characteristics, and instruments variables such as central government turnover and central state ownership, as they likely affect CEO political promotion but should be unrelated to firm performance. We then use the fitted value of promotion obtained from the logistic analysis as the instrument in the 2SLS analysis for the endogenous promotion and the relation

\footnotetext{
implicit incentive. Applying this interpretation to our setting requires caution, because political promotion in our study is not an exogenous prior, but rather positively correlated with the agent's efforts. When applied, this interpretation predicts the same substitution relation as we do. Specifically, because political promotion is endogenous, a clear prior (promotion), implies a strong effort/performance already in place. Taking to the limit, assuming political promotion sure is equivalent to assuming maximization of managerial efforts, hence little monetary incentive is in need.
} 
between promotion and compensation (Angrist and Pischke 2009). We make sure all explanatory variables and instruments are observed in years before the political promotion and compensation are observed to make sure that the regressions are predictive.

We address the reverse causality argument that the government may appoint politically favored candidates to better performing SOEs by conducting three tests. First, we review the career path of the promoted CEOs. We find that most of them start with non-political careers but a few start with political careers. Excluding those that begin with political careers gives the same results found earlier. Second, we compare the time series pattern of firm performance between firms with promoted and non-promoted CEOs. We find there is no systematic assignment of candidates. Finally, we examine the compensation to the successors of those who are politically promoted. We find that if the successor has a low ex ante likelihood of political promotion, cash pay and payperformance sensitivity increases. These results confirm that reverse causality does not drive our results.

What we learn in this paper could be generalized to other economies. If CEOs have attractive opportunities outside the managerial labor market (political or otherwise), these outside opportunities can be a valuable source of incentives if they are aligned with shareholders' interests. The lesson is also applicable to market economies, because any promotion should draw indictors of the agent's ability from the performance of past organizations led. For example, in the US, Hank Paulson was named as Treasury Secretary, not the head of a failed bank. It would be interesting to know Paulson's own assessment of the likelihood of becoming a Treasury Secretary and how this prospect motivated him during his business career.

This paper contributes to the literature in several ways. First, political promotion is different from the typical executive promotion studied in the literature, although the feature that better 
performance leads to better outcomes is common. As Kale et al. (2009) argue, CEOs are on the top hierarchy of corporations and have no promotion-based incentives. The political labor market provides CEOs an additional incentive. Second, we provide new evidence on the importance of political career concerns for providing incentives by exploiting the unique institutional environment of Chinese SOEs. Although several prior studies document a link between managerial turnover and performance in Chinese SOEs (Groves et al., 1995; Firth et al., 2006b ), few focuses on the determinants of political promotions. Third, the paper adds to our understanding of how, in an institutional environment with weak corporate governance, alternative mechanisms based on political incentives, can provide executives with motivation to enhance the performance and growth of the state economy. Consistent with the predictions of Gibbons and Murphy (1992), we

find that political career concerns substitute for monetary incentives in Chinese SOEs, suggesting that the state control and political connections not necessarily always contradicts with good economic incentives. Our results provide one possible explanation for the strong performance of Chinese firms despite the low-powered monetary incentives provided to CEOs. Our findings are also consistent with Burns, Minnick, and Starks (2012), who show that the tournament structure is largely influenced by country and culture characteristics.

The remainder of the paper is organized as follows. Section 2 describes the institutional features of the managerial labor market in Chinese SOEs and develops our hypotheses. Section 3 presents the data, discusses our sample and methodology. Section 4 presents the main empirical results, and Section 5 reports results for a number of robustness tests. Section 6 concludes with a brief summary and discussion.

\section{Institutional background and hypotheses}




\subsection{China's politically controlled personnel system and political promotions}

With the corporatization and privatization of SOEs in China beginning in 1978, many decision rights associated with the operation of the firm, such as profit retention and profit sharing schemes have shifted from the state level to the firm level (Firth et al., 2006a). Nevertheless, although the state has decentralized authority in most aspects, it retains control over personnel decisions with the ultimate authority over the selection, appointment, and dismissal of top SOE executives (Fan et al., 2007). Specially, in enterprises owned by the central government, personnel decisions are made by the State-Owned Assets Supervision and Administration Commission of the State Council (SASAC), and in enterprises owned by a local government, personnel decisions are made by the local SASACs (Chan, 2004; Bo, 2009).

Moreover, it is common in China for managers of SOEs to be also evaluated for promotion to party leadership (i.e., the Communist Party of China, CPC) positions in the firm or to positions as government officials. In China, which is founded on the principle of "party leading government," and where the government exerts substantial control over major economic resources, being appointed a CPC party leader or government official conveys significant social, career, and economic benefits. Therefore, in addition to carrying out their fiduciary duties, these CEOs are concerned about assessments from government officials that would allow them to climb the political ladder (Groves et al., 1995; Firth et al., 2006b).

To provide some perspective on the importance of political assessment for SOE managers we describe a couple of examples. Former Vice Premier of the State Council, Wu Yi, was CEO of the Beijing Yanshan Petrochemical Corporation (she rose to this position from a position as a division manager) before becoming Vice Mayor of Beijing in 1988. Following her Mayoral tenure she rose to several central government political positions, including Vice Premier of the State Council, 
before retiring in 2008. Another example is Jia Qinglin, a member of the Politburo Standing Committee of the CPC over the 2002 to 2012 period. He was CEO of the China Machinery Engineering Corporation (he rose to this position from a position as a professional engineer) before being appointed to the Politburo Standing Committee of the CPC in Fujian Province and ultimately the national Politburo Committee. Similar cases are well documented both at the central government and the provincial level, illustrating the direct linkage between the government and corporate sectors in China.

The prevalence of managers becoming politicians is a relatively unique characteristic of China's managerial labor market that distinguishes it from those in many other economies. For example, CEOs in the US and many other countries typically stand at the top of the corporate hierarchy, which eliminates internal promotion incentives (Baker et al., 1988). In the US, however, there is an active external labor market, which provides managers with ample executive career opportunities (Coles, Li, and Wang 2012). In contrast, CEOs in Chinese SOEs have limited outside opportunities since they are appointed by the state (Li and Zhou, 2005; Bo, 2009), but have ample upward potential in the political arena. Therefore, China provides an exact setting to study political promotion as a managerial incentive.

The evolution of managerial pay practices over time in China has also affected the incentives of managers in important ways. Prior to the economic reforms that began in 1978, SOE managers were simply representatives of the government and were paid according to civil service pay scale. Since that time there has been a gradual introduction of performance-based pay systems (Groves et al., 1995; Mengistae and Xu, 2004). The Central Government, through regulation and rules issued and enforced by SASAC (e.g., "Interim regulations on the administration of top executive pay” (Beijing SASAC, 2004)), encourages and monitors the use of performance-based incentives 
in the SOEs.

\subsection{Hypotheses}

Managers in China's SOEs receive direct incentives for economic performance through the use of performance-based pay, but also face implicit incentives for political advancement. We use this environment to explore the relationship between direct monetary incentives and political career concerns of managers within the unique institutional environment in China.

First, we validate that economic performance will be positively related to the likelihood that SOE managers receive political promotions, given the importance of economic development as a significant objective of the government (Qian and Xu, 1993; Li and Zhou, 2005). This validation is important as promotion has to be aligned with shareholder value to incentivize the right managerial efforts. Second, we predict that CEO compensation in Chinese SOEs is positively related to firm performance, because the use of performance-based compensation has been both encouraged and enforced through government regulation. Establishing this relation provides a benchmark for our key analysis that follows.

Applying the career concerns model in Gibbons and Murphy (1992), to the extent that political promotion is positively related to firm performance, we predict that the implicit incentives provided by political career concerns will substitute for direct monetary incentives in providing CEOs motivation to improve the economic performance of their firms. In particular, we expect that, all else equal, CEOs with a higher likelihood of political promotion will have lower pay and pay that is less sensitive to firm performance compared to CEOs with a low likelihood of political promotion. We test these predictions in our analysis.

\section{Data}




\subsection{Sample}

Our empirical tests are based on all Chinese SOEs listed (982) on the Shanghai and Shenzhen stock exchanges. Our sample starts in 2005, when individual CEO compensation data began to be disclosed, and ends in 2011. Prior to 2005, most SOEs disclosed in the annual reports only the aggregate payment to the three top executives. We exclude firms flagged with ST and *ST, which denote special treatment due to an irregularity in financial reporting and negative profits for two or three consecutive years. ${ }^{6}$ We manually check the movement of CEOs in these special treatment firms to ensure that none of the CEOs in these firms are politically promoted. We also exclude firms in the finance industry because of their unique accounting standards and firms with missing observations on the main variables used in our analysis. Our final sample comprises 756 listed firms and 4,625 firm-year observations.

We obtain information on CEO compensation, turnover, and other individual characteristics, as well as board of directors and firm financial characteristics from the Chinese Stock and Market Accounting Research (CSMAR) database and SinoFin database. The variables used in the analysis are described in Appendix A.

\subsection{Variable definitions}

\section{CEO turnover and political promotions}

We first identify all CEOs and CEO turnovers in the sample firms during 2005 to 2011. The hiring source, reason for turnover, and destination of the exiting CEO are manually collected from annual reports. In cases in which the annual reports lack sufficient detail, we collect the information from news and other online searches. Figure 1 summarizes the appointment and

\footnotetext{
${ }^{6}$ The ST flag means that the firm has negative net profits for two consecutive years and is irregularities appear in its financial statements. The *ST flag means that the firm has negative net profits for three consecutive years. These firms have a high probability of being delisted from the stock exchange due to both financial strength and regulation rules in China. We manually check all these firms and are sure that none of these firms' CEO is politically promoted.
} 
turnover of sample CEOs.

\section{INSERT Figure 1 HERE}

Panel A of Figure 1 shows that our sample contains 1,639 CEOs. Looking at hiring sources, we see that only 47 (8.45\%) of the sample CEOs are hired externally from the private sector. Looking at departures, we see that 962 CEOs leave office during the sample period. When we examine the destinations of the exiting CEOs, we identify 192 promotions (i.e., the departing CEO’s new position is more prestigious than their previous position), 218 demotions, and 552 “other” departures. Among the promotions, 152 are political promotions and 40 are non-political promotions. The non-political promotions include CEOs who become Chairman of the Board, CEOs who become CEO in the parent firm, and CEOs who become CEO or Chairman in a larger and more prestigious (SOE or investor-controlled) firm and receive higher monetary compensation. The demotion category includes CEOs who take a lower position in the same firm (168 cases) or an executive position at a smaller firm (50 cases). We manually check that none of the demotions involves a political position in the destination firm. We categorize CEOs who are also Secretary of their firm's CPC committee that step down from the CEO position but remain Secretary (87 cases) as "other" departures. ${ }^{7}$ The "other" category also includes turnovers due to retirement, health problems, personal reasons, completion of duties, and arrest $^{8}$, as well as cases without destination information (70 cases).

\footnotetext{
${ }^{7}$ Party secretaries exist at every level of the government, and in any organization that has three or more communist party members. The secretary of the CPC, the elected leader of the party members in the given institution, organizes meetings, sets the meeting agenda, assigns tasks, makes decisions on the promotion of members under his leadership, implements CPC rules, evaluates the effectiveness of implementation, communicates with leaders higher in the party structure, etc. The authority of an organization's party secretary is higher than that of the organization's operational leader, and hence the top authority in the organization. For example, the party secretary in the army supervises officers such as Colonels or Generals, the party secretary of the city government supervises the Mayor, and the party secretary in an SOE supervises the CEO.

${ }^{8}$ There is one case in which the CEO was arrested for corruption, but there is no evidence that the corruption charge was politically motivated and thus we exclude this case from the analysis rather than categorize it as a political demotion.
} 
Panel B of Figure 1 examines political promotions in more detail. In particular, we classify political promotion destinations into (a) important government positions, (b) Secretary of the firm's CPC committee, and (c) Secretary of the parent firm's CPC committee. We see that these destinations respectively account for $16.45 \%, 60.53 \%$, and $23.03 \%$ of political promotions, $2.6 \%$, 9.6\%, and 3.6\% of CEO departures, and 1.5\%, 5.6\%, and 2.1\% of sample CEOs. An example from the first group is Mr. Zhu Yanfeng, former CEO of Changchun First Auto Works Co., who became Vice Governor of Jilin province on December 11, 2007. An example from the second group is Mr. Yu Xiangqian, former CEO of TANDE Co. Ltd., who was promoted from a managerial position to become Chairman of the Board as well as Secretary of the firm's CPC committee on August 4, 2007. An example from the third group is Mr. Wang Weidong, former Chairman and CEO of Tianjin Hi-Tech Development Co. Ltd., who was promoted to CEO and Party Secretary of the parent company on July 4, 2006.

The following messages emerge from examination of CEOs' departure destinations. First, political promotions account for the vast majority of managerial promotions. Second, non-political promotions mostly occur within SOEs, with only 2 exceptions. This observation supports our claim that CEOs of Chinese SOEs have limited outside opportunities. Third, CEOs of local (central) SOEs who are promoted tend to be promoted at the local (central) level, that is, political promotions are segmented at the political jurisdiction level.

\section{Managerial compensation}

Although Chinese listed firms have been disclosing managerial compensation in the annual reports since 1998, CEO compensation was not broken out until 2005. We define CEO compensation as the sum of salary, bonus, other cash payments, and long-term incentives. Following the method in Bergstresser and Philippon (2006), we compute the long-term incentive 
value (shares and stock options) by multiplying the number of shares and stock options with the closing stock price at the end of the year. In our sample, $29.8 \%$ of the firm-year observations have data on CEO shares and 1.3\% of firm-year observations have data on stock option grants. We also conduct tests by using a dummy variable to indicate the availability long-incentives and the results are robust.

Because large perquisites exist for CEOs in China, we next hand collect information on perquisites from the footnotes of firms' cash statements. Following Gul, Cheng, and Leung (2011), our measure of perquisites includes cash expenditures on a number of operating items, such as travel, transportation, and entertainment.

Note that for CEO turnover years in our sample, we observe a partial year of compensation if the CEO leaves before the end of the year. To facilitate comparison with compensation in nonturnover years, we annualize the partial year of compensation in the turnover year.

\section{Firm performance}

Our measures of firm performance are return on assets $(R O A)$, return on sales (ROS), Stock return, and Tobin's $Q$, defined respectively as the ratio of net income to the book value of total assets, the ratio of net income to total sales, the annual change in stock price, and the sum of total liabilities and total market capitalization over total assets. In the regression analysis, we employ industry-adjusted performance, which we calculate as the difference between the firm-specific and industry-median values of the performance measure.

We expect accounting performance to deliver more consistent and robust results than stock market performance in explaining managerial compensation and promotions in China for two reasons. First, according to the official Guidelines for Performance Evaluation of CEOs of Central State Owned Enterprises, SOEs are explicitly required to evaluate performance using specific 
accounting metrics. Stock prices are not used to benchmark CEO performance due to trading restrictions on state-owned shares. Although the split-share structure reform started in 2005 aims to make all shares tradable, non-tradable shares still account for the majority of total shares in many companies due to the staged implementation of the reform. In addition, a large fraction of shares continue to face restrictions that preclude active trading on the open market. These trading restrictions also help explain the rarity of stock-based CEO compensation in SOEs. Furthermore, stock market trading in China is noisy and reflects little firm-specific information (Morck, Yeung, and Yu, 2000), and hence changes in stock prices are not regarded as indicative of actual firm performance.

Control variables

We control for several firm and CEO characteristics shown by prior literature to affect managerial compensation. In particular, we include Firm size (log of assets), Leverage (total debt to total assets), Board size (total number of board members), Board independence (number of independent directors over number of board members), $C E O$ age, CEO tenure, and CEO duality (equals 1 if the CEO is also Chairman of the Board). Following Li, Meng, Wang, and Zhou (2008), we also control for CEOs' bargaining power by including CEO education, CEO political connection, and CEO pay gap between CEO and other vice executives in the same firm. Following Fan et al (2007), we define a CEO as politically connected if the CEO was a former or currently is a government official, military officer, or a member of the NPC or CPPCC.

\subsection{Summary statistics}

Summary statistics for the variables are presented in Table 1 . We winsorize the continuous variables at the $1 \%$ distribution tails on both sides. Panel A summarizes CEO compensation. As the panel shows, mean (median) CEO cash compensation is 521,234 (330,000) RMB, which is 
equivalent to approximately 76,652 (48,529) USD. While these numbers seem small compared to US values, when we adjust them by firm size they are quite similar to those in other countries such as Italy, France, and Japan. ${ }^{9}$ Furthermore, when we compare these values to 85,000 $(60,000)$ RMB for 2000 as reported by Firth et al. (2007), we find that average CEO compensation has increased more than 6 times between 2000 and 2011. In addition, perquisites are huge, with a mean of 3.13 million RMB, which is equal to approximately 0.46 million USD and is 6 times cash compensation.

Without surprise, the average compensation for CEOs in SOEs is well above the income for average Chinese people. Using year 2011's numbers as an example, the average annual compensation for CEOs of SOEs is 488,000 RMB. It is 11 times higher than that of employee of SOEs, which is 43,483 RMB and 14 times higher than GDP per capita of the country, which is 35,181RMB based on the China Statistical Yearbook of 2012.

\section{INSERT TABLE 1 HERE}

Panel B of Table 1 summarizes firm characteristics. Average firm size measured using total assets is 9,070 million RMB, which is equal to approximately 1.3 billion USD. On average, ROA is $3.17 \%$, ROS is $4.85 \%$, and Tobin's Q is 1.63 . Stock market returns are large and volatile, with a mean of $48.58 \%, 25 \%$ quartile of $-32.22 \%$, and $75 \%$ quartile of $106.92 \%$. Leverage, measured as total liabilities divided by total assets, is $49.12 \%$ on average.

Panel C of Table 1 summarizes CEO and board characteristics. The average age of CEOs in our sample is 47.63 and their average tenure is 3.61 years. In comparison, the average tenure of CEOs in the US is 4.8 years over the 2000 to 2010 period (Luo, Kanuri, and Andrews, 2013). The shorter tenure in Chinese SOEs indicates higher CEO turnover in China than the US. Average

\footnotetext{
${ }^{9}$ According to Watson Wyatt's world-wide salary survey (2009), for a firm with 1 to 3 billion USD in assets, CEO annual pay is approximately 2 million USD in the US, but only 0.5 million USD in Italy, France, and Japan. For CEOs in our sample, average firm size is 3 billion RMB and average CEO compensation is 0.3 million RMB over the 2002 to 2007 period.
} 
board size is 9.6 members in Chinese SOEs, and only 3.4 board members are independent on average. This contrasts with the US, where nearly all boards of listed firms have a majority of independent directors.

Finally, Panel D of Table 1 reports the distribution of CEO promotions over the sample period. The number of political promotions exhibits the lowest value of 16 in 2009 and the highest value of 28 in 2005. The other types of promotion, including becoming CEO of the parent firm without political involvement and becoming CEO of a privately controlled firm with higher compensation, occur with a frequency of less than 9 cases per year. The relative rarity of non-politically related promotions is consistent with CEOs facing limited outside opportunities in the managerial labor market in China.

\section{Empirical results}

In this section we examine the CEO political promotion in Chinese SOEs and how political and monetary incentives are interacted with each other in affecting CEO behavior. We first analyze competition and survival among CEOs. We next examine the determinants of CEO political promotions. Finally, we explore how political promotion incentives are related to monetary incentives.

\subsection{CEO political promotions and firm performance}

Table 2 presents univariate results on firm performance, firm characteristics, and compensation for three groups: political promotions, non-political (i.e., managerial) promotions, and others, which include no turnovers, demotions, and normal turnovers. For CEO turnovers, the variables of interest are observed the year before the CEO turnover if the turnover occurs within the first half of the year, or the year of the CEO turnover if the turnover occurs within the second half of the year (Huson et al., 2001). For CEOs who remain in their position throughout the sample period, 
we take all sample years’ observations.

In Panel A of Table 2, we see that the mean (median) ROA, ROS, and Tobin's Q of the political promotion group are 6.45\% (5.41\%), 10.75\% (8.67\%), and 1.73 (1.29). By way of comparison, the non-political promotion group has a mean (median) ROA, ROS, and Tobin's Q of 2.57\% (1.82\%), 5.42\% (2.75\%), and 1.41 (1.37). These three firm performance measures are thus significantly higher in the political promotion group than in the non-political promotion group. Stock performance, however, is not significantly different between the two groups. Similarly, accounting performance measures are significantly lower in the non-promotion group than those in the political promotion group, but this pattern does not hold for market performance. These results suggest that political promotions are driven at least in part by economic performance.

Panel A of Table 2 also shows that mean (median) CEO pay is 394,153 RMB (309,500 RMB) in the political promotion group, which is lower than the mean (median) pay of 473,135 RMB (331,500 RMB) in the non-political promotion group. The magnitude of the difference is substantial, with the percentage change in mean equal to 20\%. CEO pay in the political promotion group is also significantly lower than that in the no-promotion group. In contrast, firm size in the political promotion group is much larger (assets of 7,900 vs. 5,300 or 7,020 million RMB) than in the non-political promotion or no-promotion groups. Furthermore, CEOs in the political promotion group have fewer perquisites, suggesting that differences in total compensation, if they could be measured accurately, are likely to be larger between the political promotion group (lower compensation) and the other groups (higher compensation). Further, in addition to managing much larger firms, CEOs who are promoted to political positions tend to be slightly younger and have longer tenure as CEO at the time of promotion compared to CEOs in the non-political promotion group. 
In Panel B of Table 2, we compare CEO compensation between the three groups by year. Total CEO compensation in the political promotion group is lower than that in the no-promotion group for all years, and is also lower than that in the non-political promotion group toward the end of the sample period.

In summary, the results in Table 2 show that firms managed by politically promoted CEOs exhibit stronger performance but offer lower monetary compensation to their CEOs compared to no-promotion firms. Compared to other turnovers, the political promotion group exhibits similar performance and lower size-adjusted compensation. These results provide initial evidence consistent with our hypothesis that career concerns associated with political promotion provide implicit incentives for value maximization that substitute for direct monetary incentives.

\section{INSERT TABLE 2 HERE}

\subsection{Political career concerns and compensation in Chinese SOEs}

To provide evidence on the importance of career concerns in Chinese SOEs, we examine the determinants of political promotions as well as the interactions between political career incentives and monetary incentives. We proceed in two steps using an augmented instrumental variables approach to control for the endogeneity of promotion decisions.

In the first step we estimate a logit model of the likelihood of political promotion. The dependent variable is Promotion, an indicator equal to one if the CEO is politically promoted in the given year. The independent variables include lagged firm performance (the industry-adjusted performance in the past year $)^{10}$, firm size, employee number, CEO age, CEO tenure, board size, and board independence, etc. To the extent that political promotions include economic

\footnotetext{
${ }^{10}$ In Huson et al. (2001) on CEO turnover, the analyses use past year's firm performance if the turnover occurred in the first half of the year or the current year's firm performance if the turnover occurred in the second half of the year. (
} 
performance in evaluation, we expect past performance to be positively related to the likelihood of political promotion. As we will use the expected promotion to explain the CEO compensation in later analyses, all explanatory variables here are observed one year before the compensation is observed.

Because promotion and compensation are likely determined jointly, and the fitted values of promotion will be used later as the instrument in the 2SLS analysis, we include two instruments for identification. The first is Central government ownership, an indicator variable equal to one if the central government is the ultimate controlling shareholder of the firm. All else equal, we expect the incidence of political promotion to be higher in firms under the direct control of the central government. The second instrument is Central government turnover, an indicator variable equal to one if the year is 2005 or 2008, the years in our sample coinciding with turnovers in key central government positions, such as Chairman/Prime Minister of the State, Chairman of the Communist Party, and Chairman of the Army. We conjecture that turnover at the top levels of the central government coincide with opportunities for political promotion at other levels of government. ${ }^{11}$ The regression also includes industry and year fixed effects.

In the second step, we apply a 2SLS procedure, where the fitted values of Promotion from the logistic analysis above are used as the instruments in the $1^{\text {st }}$ stage and all exogenous explanatory variables in the logistic regressions are included as the controls. In the $2^{\text {nd }}$ stage, we regress the natural log of CEO compensation on firm performance and the prediction of Promotion

\footnotetext{
${ }^{11}$ Our assumption is that these instruments are correlated with the promotion decision but uncorrelated with the error term in the compensation regression. The relevance condition is satisfied as the results show below. Although the exclusion condition (e.g., Roberts and Whited, 2012) is generally untestable, our instrument using central government turnover is largely exogenous: the timing of turnover for the Premier in China and the Chairman of the CPC are determined by the political institution. Every five years, the CPC holds a meeting attended by national CPC members to elect a Central Committee. The Central Committee approves major government decisions and elects a standing committee, including the Premier and the CPC Chairman. There is no reason to believe that this exogenous timing would be correlated with CEO compensation.
} 
(Promõtion ) from the $1^{\text {st }}$ stage. We use this augmented 2SLS because Promotion is a dummy variable and its determinants likely follows a non-linear function (Angrist and Pischke 2009). ${ }^{12}$ To examine the extent to which incentives from political career concerns substitute for performancebased monetary incentives, we include the interaction term between Promõtion and the firm performance measures.

As control variables, the regressions in both stages include firm size, leverage, employee number, CEO age, CEO tenure, CEO duality (coded as one if the CEO is also Chairman of the Board and 0 otherwise), board size, independence, CEO education, CEO pay gap and CEO political connection, as well as firm and year fixed effects. To avoid look-ahead bias, the performance, controls, and year fixed effect entered into the regression are all observed one year before the compensation is observed. All standard errors are robust and clustered at the firm level.

Panel A of Table 3 reports results from the logit regression where the political promotion indicator is the dependent variable. In three out of four specifications (the exception is stock return), the coefficient estimates on the past firm performance measures are positive and significant at the $1 \%$ level, indicating that economic performance of the CEO is an important determinant of whether the CEO is promoted to a political position. Specifically, the marginal effect for ROA indicates that a $1 \%$ increase in ROA is associated with a $0.26 \%$ increase in the likelihood of political promotion. This effect is economically important given that political promotions represent only $15 \%$ of turnovers or $9 \%$ of all CEOs in the sample.

\footnotetext{
${ }^{12}$ As the instruments in the 2SLS are the fitted values from the logistic analysis, the identification essentially relies on the nonlinear logistic analysis where central government ownership and central government turnover are the exogenous instruments. If the non-linear model provides better deterministic prediction than a linear model, this nonlinear-fits-as-instruments 2SLS has the advantage of resulting more efficient estimation than those using a linear model in the 1st stage (Newey 1990). We compare the results from this augmented 2SLS with those from using linear fitting or non-linear directly in the $1^{\text {st }}$ stage. The comparison is consistent with Newey (1990)'s prediction, and thus confirms that our logistic deterministic model for political promotion and the non-linear-fits-as-instruments 2SLS are the correct procedure to use in this setting.
} 
The coefficients on Central government ownership and Central government turnover are positive as expected and significant at the $5 \%$ level or better, indicating that political promotions are indeed more likely when the ultimate controlling shareholder is the central government and in years in which there is turnover at the top levels of government. The joint test of the instruments is significant at the $1 \%$ level, which verifies that the relevance requirement for the instruments is satisfied.

Panel B of Table 3 reports results from the 2SLS regressions. The results from the $1^{\text {st }}$ stage, a linear prediction for promotion with the fitted values from the logic analysis above and all other exogenous variables, are not tabulated here but available upon request. The results from the $2^{\text {nd }}$ stage regressions with the log of CEO compensation as the dependent variable are reported here. As seen in the table, perquisite is positively associated with CEO compensation, confirming that using CEO pay alone as the dependent variable biases the results downwards. CEO pay is positively related to firm performance over the CEO's tenure, again with the exception of stock market returns. More importantly, the coefficients on both Promõtion (the prediction of Promotion from the $1^{\text {st }}$ stage) and its interactions with ROA, ROS and Tobin's Q are negative, suggesting that compensation to CEOs with a higher likelihood of political promotion is lower and less sensitive to firm performance. ${ }^{13}$

\section{INSERT TABLE 3 HERE}

This pattern is even more striking when political promotions are compared with non-political promotions. In Panel A of Table 4, we apply a competing risk model to analyze opportunities for political and non-political promotions. The outcome variable (for each CEO-year) takes three

\footnotetext{
${ }^{13}$ Many studies have used regression approach to estimate pay-performance sensitivity. The most widely cited one is Jensen and Murphy (1990), where performance is measured in shareholder dollar value. Other studies such as Core, Holthausen, and Larcker (1999) and Firth, Fung, and Rui (2006) use ROA and ROE in regressions to estimate payperformance sensitivity.
} 
discrete values: 2 for political promotion, 1 for other promotion, and 0 otherwise (no turnover or demotion), where 0 is the survival indicator in the model, 2 and 1 are alternative competing risk, not ordered. We find that all four performance measures are positively associated with the probability that a CEO is politically promoted (e.g. the sub-hazard ratio for ROA is as high as 4.39). The relations are significant at the $1 \%$ level, except for stock return. Firm size is also significantly related with the probability of political promotion. As expected, age has a negative impact on the probability of political promotions. Central government ownership compared to local government ownership makes significant difference on the competition outcome, and central government turnover also affects political promotions, with a hazard ratio of around $1.35 \%$ that is significant at the $5 \%$ level.

In Panel B of Table 4, we repeat the final results from the fitted-value-as-instruments 2SLS analysis for the subsample that only includes promoted CEOs. We find that the coefficients on Promõtion and its interactions with ROA and ROS are significantly negative. In the regression with ROA as the performance measure, the coefficient on political Promõtion is -0.33 , significant at the $1 \%$ level, implying that CEOs with a higher likelihood of political promotion receive lower monetary compensation compared to other types of promotions. Moreover, the negative coefficients on the interactions between political Promõtion and both ROA and ROS indicate that CEO compensation is also less sensitive to firm performance when there is a presence of impending political promotion.

In all regressions, the results when using the stock market-based performance measure are not significant. This insignificance however is consistent with stock market returns not being viewed as an effective measure of performance in China and hence not being recommended as the basis for performance evaluation in the government's official guidelines. 
Overall, the findings in Table 3 and Table 4 support our hypotheses. In particular, consistent with the central government's focus on economic development as an important part of its political agenda, the likelihood of a Chinese SOE's CEO being promoted to a political position is positively related to firm performance. Further, consistent with the predictions of managerial career concerns models (e.g., Gibbons and Murphy, 1992), our results indicate that in China the implicit incentives provided by political career concerns substitute for direct monetary incentives.

\section{INSERT TABLE 4 HERE}

\subsection{Robustness tests}

In Table 3 and 4, to avoid look ahead bias in analyzing CEO compensation, we use industryadjusted performance observed one year before the compensation is observed to predict the future promotion. While this is a correct approach to demonstrate the substitution effect between promotion incentive and monetary incentive, it sacrifices the rigorousness in examining the determinants of political promotion, because the promotion decision is likely to consider more than one year of performance information. Therefore, we use the CEO performance over the tenure to conduct robustness tests for the promotion determinants and find that the results are robust and the explanatory power is also higher. These untabulated results are available upon request.Moreover, as our examination of the substitution effect between the career incentive and monetary incentive relies on the estimation of the coefficient on the interaction of promotion*performance, in which promotion is predicted with performance, we need to make sure the negative coefficient is not driven by a concave relation between pay and performance. We add a quadratic term of performance measures into the $2^{\text {nd }}$ stage of the regression, where we regress CEO compensation on predicted promotion probability, performance, and interactions. We find that the coefficients on the quadratic term of performance measures are either insignificant or 
negatively significant, confirming a concave pay-performance relation. However, the coefficients on promotion and the interactive term of promotion and performance remain negative and significant, suggesting that the decrease of pay-performance relation when promotion probability increase is not driven by the concave pay-performance relation. These untabulated results are available upon request.

\section{Tests on Reverse Causality}

One concern with our analysis is the potential for reverse causality. Specifically, it is possible that the central government assigns candidates that it would like to promote politically to firms with good economic performance, since the government maintains the ultimate authority regarding CEO appointments in SOEs. To address this concern, we first carefully review the career paths of all CEOs in our sample that are politically promoted. We find that most of these CEOs started their careers as non-political professionals before taking a management position. As Figure 1 shows, of the 152 politically promoted CEOs, $66.45 \%$ were hired internally, with only 10 of these coming from a political position. Among the externally hired CEOs, prior experience in a political position is higher, accounting for one-fifth of political promotions or $1.8 \%$ of the total sample of CEOs. In robust tests we find that excluding these cases has no meaningful effect on the results reported above. Nevertheless, below we perform two direct tests to show that the reverse causality does not drive our results.

\subsection{Firm performance around CEO assignments and promotions}

In Table 5, we conduct event time analysis of firm performance across the political promotion group, the non-political promotion group, and the no-promotion group. The event time begins in the year before the sample CEOs (with turnovers) took the position and follows these CEOs through the year they leave the CEO position. We test for the differences between the political 
promotion groups, the other promotion group, and the no-promotion group

Comparing firm performance in the year prior to the CEO appointment (year t-1), the table shows that none of the performance measures is significantly different across the three groups. For both promotion groups, firm performance begins to improve in the year these CEOs are appointed and continues to improve up until the time they are promoted. The improvement trend is clearer using the accounting performance measures than market performance. There is no evidence that politically promoted CEOs are appointed to firms that are already performing well. Denoting the appointment year as $t$ and the departure year as $\mathrm{T}$, we see that ROA more than doubles from t-1 (mean of 2.52\%) to $\mathrm{T}$ (mean of 6.45\%) for the political promotion group and increases from $2.65 \%$ to $4.57 \%$ for the non-political promotion group. The same pattern does not exist, however, for the no-promotion group, with ROA decreasing from $2.13 \%$ in the year prior to appointment to $1.55 \%$ in the year of departure.

In short, the performance patterns suggest that politically promoted CEOs are not systematically assigned to firms with better performance. Instead, the results are consistent with the view that CEOs are promoted politically only after improving the performance of their firms.

\section{INSERT TABLE 5 HERE}

We next compare firm performance over time within each group. As Table 6 shows, firm performance within both the political promotion group (Panel A) and the non-political promotion group (Panel B) increase significantly over the sample CEOs' tenure. Both ROA and ROS in the year of CEO promotion as well as over the CEOs' tenure are significantly higher than in the year the CEOs are initially appointed or the year prior to appointment. Results using the accounting performance measures are all statistically significant. Specifically, for the political promotion group, ROA in the turnover year, $\mathrm{T}$, is $6.45 \%$ at the mean (6.33\% at the median), which is higher 
than the $2.52 \%$ (3.55\%) in year $\mathrm{t}-1$, the year before the CEO was appointed, with the difference significant at the $1 \%$ level for both the mean and the median. Similarly, ROS in the non-political promotion group increases from 3.98\% (4.16\%) in year t-1 to $10.42 \%$ (8.75\%) in year T, with the difference significant at the $1 \%$ level.

Such improvement, however, does not exist for the group in which CEOs depart for nonpromotion reasons (Panel C of Table 6). Furthermore, the performance improvement pattern is not as pronounced for the market performance measures as for the accounting performance measures, which again is consistent with our prior on the irrelevance of market returns in the government's guidelines on managerial evaluation.

\section{INSERT TABLE 6 HERE}

Overall, the results in Tables 5 and 6 show that politically promoted CEOs are not simply assigned to firms with better performance, but instead firm performance increases significantly during politically promoted CEOs’ tenure. The pattern in performance improvement is similar to that of CEOs promoted to non-political positions, but clearly differs from that of the no-promotion group.

\subsection{Successor's compensation}

Finally, we investigate compensation to the successors of politically promoted CEOs. We first predict the likelihood of each successor being politically promoted in the future, using the same approach as in the first step of Table 3. Based on the predicted likelihood, we flag those successors whose likelihood of political promotion is lower than the median. We then conduct analysis similar to the second stage of Table 3, with one change: we add an indicator for a low likelihood of political promotion and its interaction with the performance measures as explanatory variables.

In Table 7 we find that successors who have a low likelihood of future political promotion 
receive higher compensation and have stronger pay-for-performance sensitivity compared to successors who have a high likelihood of future political promotion, even though the predecessors of both types of successors were actually political promoted. The increases in compensation and pay-for-performance sensitivity are significant at the $1 \%$ level.

\section{INSERT TABLE 7 HERE}

\section{Conclusions}

In China, the government is often the largest owner of SOEs and hence retains ultimate control over these firms' personnel decisions, including the selection, appointment, and dismissal of top executives. Because CEOs of many listed SOEs are appointed by the government, are evaluated annually according to their performance, and have limited options in the managerial market, these CEOs often have political career aspirations. If political promotions are based on non-economic factors, incentives for political promotion may interfere with incentives to maximize firm value. To the extent that the central government values strong economic performance, these politicalbased career concerns, however, provide managers with powerful incentives to maximize firm value. This paper examines the determinants of CEOs' political promotion and explores how political career concerns interact with monetary incentives given to CEOs.

We find that the likelihood of political promotion exhibits a strong positive relation with firm performance, indicating that CEOs' political career concerns might be not be necessary to contradict with value maximization in Chinese SOEs. Moreover, consistent with models of career concerns, we document that political promotion incentives substitute for direct monetary incentives. Overall, our analysis indicates that both explicit (compensation-based) and implicit (political-based) incentives are effective in influencing managerial behavior.

This paper is among the first to document that CEOs' political career concerns provide strong 
incentives that might align their interests with those of shareholders. The paper helps improve our understanding of how China's state-related sector has achieved significant growth despite an environment characterized by low-powered monetary incentives and weak corporate governance.

The evidence suggests that outside career opportunities can provide managerial incentives, which is particularly useful when offering monetary incentive faces certain institutional constraints.

\section{Reference}

Angrist, J., Pischke, J., 2009. Mostly harmless econometrics: An empiricist’s companion. Princeton University.

Baker, G. P., Jensen, M. C., Murphy, K.J., 1988. Compensation and incentives: practice versus theory. Journal of Finance 43(3), 593-616.

Beijing SASAC (State-Owned Assets Supervision and Administration Commission of the State Council), 2004. Interim regulations on the administration of top executive pay in Beijing SOEs.

Bergstresser, D., Philippon, T., 2006. CEO incentives and earnings management. Journal of Financial Economics 80(3), 511-529.

Brickley J. A., Coles J., Linck J. S. 1999. What happens to CEOs after they retire? New evidence on career concerns, horizon problems, and CEO incentives. Journal of Financial Economics 52 (3), 341-377.

Burns, N., K. Minnick, and L. Starks. 2012. CEO tournaments: A cross-country analysis of causes, cultural influences and consequences. Working paper. University of Texas at Austin.

Cichello, M. , Fee, C. ., Hadlock, C. J. , \& Sonti, R. 2009. Promotions, Turnover and Performance Evaluation: Evidence from the Careers of Division Managers. The Accounting Review, 84 (4), 1119-1143.

Coles, J.L., Daniel, N.D., and Naveen, L., 2006, Executive compensation and managerial risk taking. Journal of Financial Economics 70, 431-468.

Coles, J.L., Z.F.Li, and Y.A. Wang, 2012. Industry Tournament Incentives. Working paper, Arizona State University. 
Core, J. E., Holthausen. R. W., Larcker, D. F., 1999. Corporate governance, chief executive officer compensation, and firm performance. Journal of Financial Economics 51(3): 371406.

Fama, E. F., 1980. Agency problems and the theory of the firm. Journal of Political Economy 88: 288-307.

Fan, J. P. H., Wong, T. J., Zhang, T. Y., 2007. Politically connected CEOs, corporate governance, and post-IPO performance of China’s newly partially privatized firms. Journal of Financial Economics 84(2): 330-357.

Firth, M., Fung, P. M. Y., Rui, O. M., 2006a. Corporate performance and CEO compensation in China. Journal of Corporate Finance 12(4): 693-714.

Firth, M., Fung, P. M. Y., Rui, O. M., 2006b. Firm performance, governance structure, and top management turnover in a transitional economy. Journal of Management Studies 43(6): 1289-1330.

Firth, M., Fung, P., Rui, O., 2007. How ownership and corporate governance influence chief executive pay in China’s listed firms. Journal of Business Research 60, 776-785.

Gibbons, R., Murphy, K. J., 1992. Optimal incentive contracts in the presence of career concerns: Theory and evidence. Journal of Political Economy 100, 468-505.

Goel, A., Nanda, V., Narayanan, M., 2004. Career concerns and resource allocation in conglomerates. Review of Financial Studies 17(1), 99-128.

Groves, T., Hong, Y., Mcmillan, J., Naughton, B., 1995. China’s evolving managerial labor market. Journal of Political Economy 103(4): 873-892.

Gul, F., Cheng, L., Leung, T.Y., 2011. Perks and the informativeness of stock prices in the Chinese market. Journal of Corporate Finance 17, 1410-1429.

Holmstrom, B., 1999. Managerial incentive problems: A dynamic perspective. Review of Economic Studies 66 (1), 169-182.

Huson, M., Parrino, R., Starks, L., 2001. Internal monitoring mechanisms and CEO turnover: a long-term perspective. Journal of Finance 56,2265-2298.

Jensen, Michael C. and Kevin J. Murphy, 1990. Performance Pay and Top-Management Incentives Journal of Political Economy, 98(2), 225-264.

Jenter, D., Kanaan, F., 2015. CEO turnover and relative performance evaluation. Journal of Finance 70(5), 2155-2184. 
Kale, J. R., Reis, E., Venkateswaran, A., 2009. Rank-order tournaments and incentive alignment: The effect on firm performance. Journal of Finance 64 (3): 1479-1512.

Kini, O., and R. Williams, 2012. Tournament incentives, firm risk, and corporate policies, Journal of Financial Economics 103(2), 350-376.

Lazear, E.P., Rosen, S., 1981. Rank-order tournaments as optimum labor contracts. Journal of Political Economy 89, 841-864.

Li, D., 1998. Changing incentives of the Chinese bureaucracy. American Economic Review 88, 393-397

Li, H., Zhou, L., 2005. Political turnover and economic performance: The incentive role of personnel control in China. Journal of Public Economics 89(9): 1743-1762.

Mengistae, T., Xu, L. C., 2004. Agency theory and executive compensation: The case of Chinese state-owned enterprises. Journal of Labor Economics 22(3): 615-637.

Morck, R., Yeung, B., Yu, W., 2000. The information content of stock markets: Why do emerging markets have synchronous stock price movements? Journal of Financial Economics 58(12), 215-260.

Milbourn, T., Shockley, R., Thakor, A., 2001. Managerial career concerns and investment in information. Rand Journal of Economics 32(2), 334-351.

Pae, S., Song, C., Yi, A., 2016. Career concerns and management earnings guidance. Contemporary Accounting Research 33(3), 1172-1198.

Qian, Y., Xu, C., 1993. The M-form hierarchy and China’s economic reform. European Economic Review 37(2-3), 541-548.

Roberts, M., Whited, T., 2012. Endogeneity in Empirical Corporate Finance, The Wharton School and NBER, Working paper.

Song, F., Thakor, A., 2006. Information control, career concerns, and corporate governance. Journal of Finance 61(4), 1845-1896.

Yermack, D., 2004. Remuneration, retention, and reputation incentives for outside directors. Journal of Finance 59(5), 2281-2308. 
Appendix: Variable definitions

\begin{tabular}{ll}
\hline Variable & Definition \\
\hline $\begin{array}{ll}\text { Panel A: Managerial compensation } \\
\text { CEO compensation (CEO pay) }\end{array}$ & $\begin{array}{l}\text { CEO’s total compensation, including salary, bonus and long-term incentives. } \\
\text { The value of the stocks and options are computed by multiplying shares and } \\
\text { options held with stock prices at the end of the year. We use the log of this } \\
\text { value in the regressions. } \\
\text { Firms' cash expenditures on travel, transportation, entertainment, and public } \\
\text { relations. An item reported in the footnote of the cash flow statement. We } \\
\text { use the ratio of this value to total sales in the regressions. }\end{array}$
\end{tabular}

Panel B: Firm performance

Return on assets (ROA)

Return on sales (ROS)

Stock return

Tobin's Q

Net income/total assets.

Net income/sales.

Annual stock return.

(Market value of tradable shares + book value of non-tradable shares + liabilities)/book value of total assets.

\section{Panel C: CEO characteristics}

Political promotion

Non-political promotion

Demotion

CEO age

CEO tenure

CEO duality

CEO education

CEO pay gap

CEO political connection

Equals 1 if the CEO is politically promoted and 0 otherwise.

Equals 1 if the $\mathrm{CEO}$ is promoted to a higher managerial position and 0 otherwise.

Equals 1 if the CEO moves to a lower position or smaller firm and 0 otherwise.

The age of the CEO. We use the log of this value in the regressions.

The number of years as the firm's CEO. We use the log of this value in the regressions.

Equals 1 if the CEO also chairs the board.

The number of years of schooling. We use the log of this value in the regressions.

Difference between CEO pay and average pay of other top three executive pay. We use the log of this value in the regressions.

Equals 1 if the CEO is politically connected (a former or current government official, military officer, or a member of the NPC or CPPCC) and 0 otherwise.

\section{Panel D: Firm characteristics and corporate governance}

Firm size

Leverage

Board size

Board independence

Employee

Central government ownership

Central government turnover
Firm's total assets. We use the log of this value in the regressions.

Total debts/total assets in book value.

The number of directors on the board. We use the log of this value in the regressions.

The number of independent directors on the board. We use the proportion of independent directors on the board in the regressions.

The number of employees. We use the log of this value in the regressions. Equals 1 if the firm is owned by the central government and 0 otherwise. Equals 1 for 2005 and 2008, when there were turnovers in the key central government positions - Chairman/Prime minister of the state, Chairman of the Communist Party and Army, and 0 otherwise. 
Figure 1: The hiring sources and departure destinations of sample CEOs.

Panel A: All CEOs in the sample

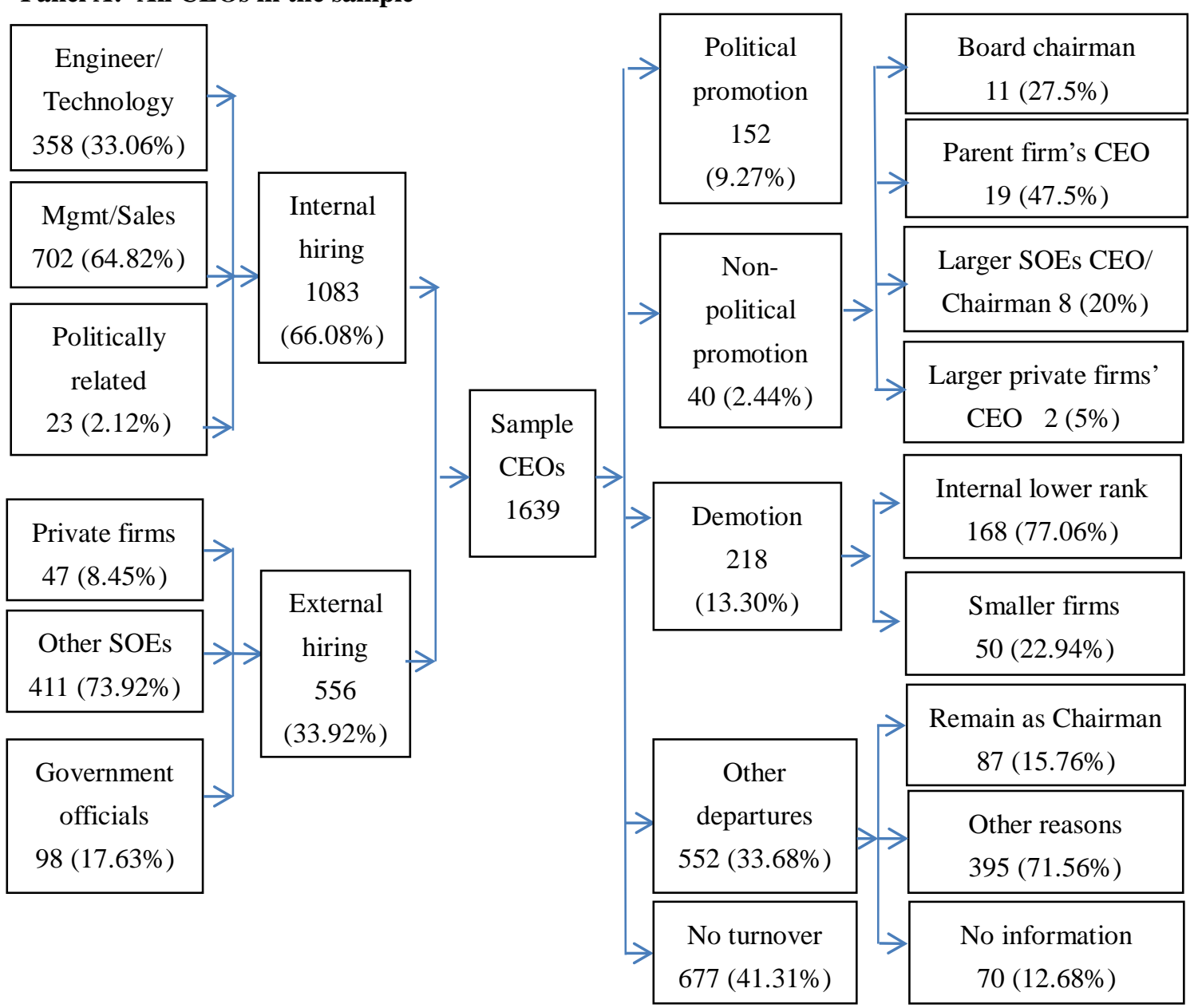

Panel B: Politically promoted CEOs in the sample

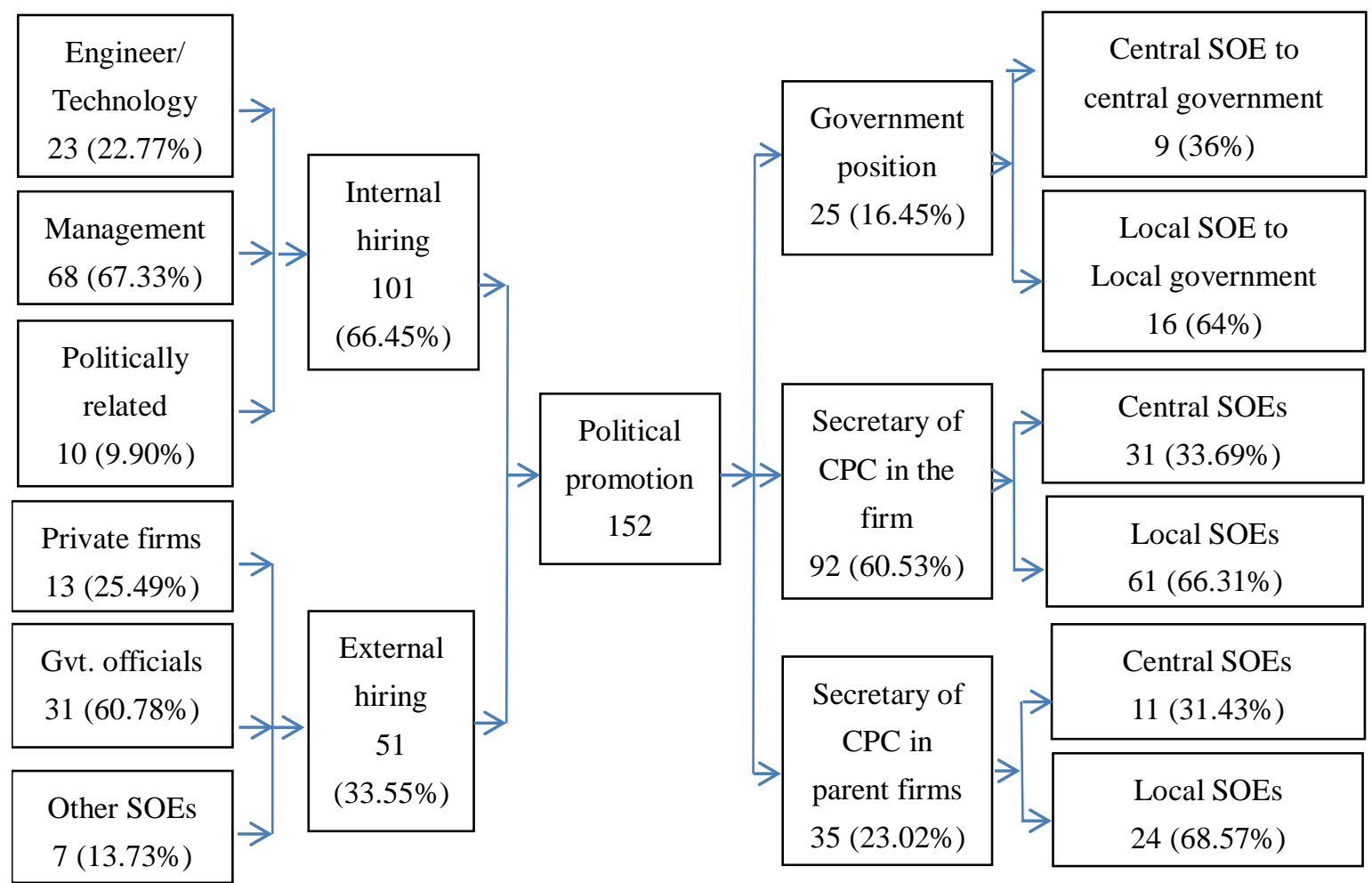




\section{Table 1: Summary statistics}

This table reports sample summary statistics of the raw values for CEO compensation, firm characteristics, and CEO characteristics for the 2005 to 2011 period. CEO pay is the total cash compensation, bonus, and long-term incentives (value of shares and stock options) Perquisites are firms' cash expenditures on travel, transportation, entertainment, public relationship, etc., an item reported in the footnote of the cash flow statement. All values are in RMB.

\begin{tabular}{|c|c|c|c|c|}
\hline Variable & Mean & Median & 25\% quartile & 75\% quartile \\
\hline \multicolumn{5}{|l|}{ Panel A: Executive compensation } \\
\hline CEO pay & 521,234 & 330,000 & 187,571 & 575,000 \\
\hline Perquisites (million) & 3.13 & 0.89 & 0.32 & 2.38 \\
\hline \multicolumn{5}{|l|}{ Panel B: Firm characteristics } \\
\hline Total Assets (millions) & 6,070 & 2,980 & 1,520 & 6,750 \\
\hline $\mathrm{ROA}(\%)$ & 3.17 & 2.92 & 1.05 & 5.34 \\
\hline ROS (\%) & 4.85 & 4.31 & 1.48 & 9.59 \\
\hline Tobin’s Q & 1.63 & 1.30 & 1.04 & 1.85 \\
\hline Stock returns (\%) & 48.58 & 11.59 & -32.22 & 106.92 \\
\hline Central state ownership (dummy) & 0.23 & 0 & 0 & 0 \\
\hline Leverage (\%) & 49.12 & 51.91 & 36.69 & 64.77 \\
\hline Employee & 5,420 & 2,323 & 1,055 & 5,338 \\
\hline \multicolumn{5}{|c|}{ Panel C: CEO characteristics and board characteristics } \\
\hline CEO age & 47.63 & 47 & 43 & 52 \\
\hline CEO tenure & 3.61 & 3.25 & 1.5 & 5.33 \\
\hline CEO duality & 0.09 & 0 & 0 & 0 \\
\hline CEO education & 16.22 & 16 & 16 & 18 \\
\hline CEO pay gap & 265,926 & 173,993 & 108,350 & 350,000 \\
\hline CEO political connection & 0.28 & 0 & 0 & 1 \\
\hline Board size & 9.59 & 9 & 9 & 11 \\
\hline Independent director & 3.40 & 3 & 3 & 4 \\
\hline
\end{tabular}

Panel D: Frequency of promotion by year

\begin{tabular}{llrrrr} 
& $\begin{array}{l}\text { Political } \\
\text { Promotion }\end{array}$ & Other promotion & Demotion & $\begin{array}{r}\text { Other normal } \\
\text { turnover }\end{array}$ & No-turnover \\
2005 & 28 & 6 & 31 & 82 & 499 \\
2006 & 18 & 7 & 33 & 79 & 545 \\
2007 & 17 & 8 & 30 & 81 & 564 \\
2008 & 25 & 7 & 34 & 71 & 626 \\
2009 & 16 & 9 & 30 & 86 & 601 \\
2010 & 23 & 0 & 32 & 79 & 627 \\
2011 & 25 & 3 & 28 & 74 & 553 \\
\hline
\end{tabular}


Table 2: Univariate comparison of performance and compensation by CEO promotion categories

This table compares the mean (median) values for all variables across three CEO promotion categories: political promotions, non-political promotions, and others, which include no turnover, demotion, or normal turnover. Tstatistics (and Wilcoxon test values) of the mean and median differences between groups are also reported. The sample covers the 2005 to 2011 period and observations are at the firm-year level.

Panel A: Firm characteristics, returns, and CEO compensation

\begin{tabular}{|c|c|c|c|c|c|}
\hline & $\begin{array}{l}\text { Political } \\
\text { Promotion }\end{array}$ & $\begin{array}{l}\text { Non-political } \\
\text { Promotion }\end{array}$ & $\begin{array}{l}\text { Difference test: } \\
\text { Political vs. } \\
\text { non-political } \\
\text { promotion }\end{array}$ & $\begin{array}{l}\text { Others } \\
\text { (no turnover or } \\
\text { no promotion) }\end{array}$ & $\begin{array}{l}\text { Difference test: } \\
\text { Political } \\
\text { Promotion vs. } \\
\text { Others }\end{array}$ \\
\hline ROA & $\begin{array}{l}6.45 \\
(5.41)\end{array}$ & $\begin{array}{l}2.57 \\
(1.82)\end{array}$ & $\begin{array}{l}6.72 * * * \\
(4.49) * * *\end{array}$ & $\begin{array}{l}3.15 \\
(2.91)\end{array}$ & $\begin{array}{l}3.32 * * * \\
(3.55)^{* * *}\end{array}$ \\
\hline ROS & $\begin{array}{l}10.75 \\
(8.67)\end{array}$ & $\begin{array}{l}5.42 \\
(2.75)\end{array}$ & $\begin{array}{l}3.88^{* * *} \\
(3.48)^{* * *}\end{array}$ & $\begin{array}{l}4.79 \\
(4.29)\end{array}$ & $\begin{array}{l}2.87 * * * \\
(3.01)^{* * *}\end{array}$ \\
\hline Tobin's Q & $\begin{array}{l}1.73 \\
(1.29)\end{array}$ & $\begin{array}{l}1.41 \\
(1.37)\end{array}$ & $\begin{array}{l}2.97 * * * \\
(-0.87)\end{array}$ & $\begin{array}{l}1.63 \\
(1.30)\end{array}$ & $\begin{array}{l}1.38 \\
(-0.03)\end{array}$ \\
\hline Stock return & $\begin{array}{l}48.27 \\
(-1.62)\end{array}$ & $\begin{array}{l}49.02 \\
(20.14)\end{array}$ & $\begin{array}{l}-0.05 \\
(-1.21)\end{array}$ & $\begin{array}{l}48.09 \\
(12.03)\end{array}$ & $\begin{array}{l}-1.22 \\
(-1.02)\end{array}$ \\
\hline CEO pay & $\begin{array}{l}394,153 \\
(309,500)\end{array}$ & $\begin{array}{l}473,135 \\
(331,500)\end{array}$ & $\begin{array}{l}-0.90 \\
(-0.12)\end{array}$ & $\begin{array}{l}553,403 \\
(356,600)\end{array}$ & $\begin{array}{l}-2.19 * * \\
(-2.64) * * *\end{array}$ \\
\hline Perquisites & $\begin{array}{l}2.85 \\
(0.87)\end{array}$ & $\begin{array}{l}2.82 \\
(1.05)\end{array}$ & $\begin{array}{l}0.17 \\
(-0.77)\end{array}$ & $\begin{array}{l}3.18 \\
(1.25)\end{array}$ & $\begin{array}{l}-2.02 * * \\
(-2.31)^{* *}\end{array}$ \\
\hline Employ & $\begin{array}{l}5780 \\
(2948)\end{array}$ & $\begin{array}{l}5408 \\
(2797)\end{array}$ & $\begin{array}{l}0.32 \\
(0.25)\end{array}$ & $\begin{array}{l}5287 \\
(2309)\end{array}$ & $\begin{array}{l}1.78^{*} \\
(2.25)^{* *}\end{array}$ \\
\hline CEO age & $\begin{array}{l}45.96 \\
(45)\end{array}$ & $\begin{array}{l}46.72 \\
(46)\end{array}$ & $\begin{array}{l}-0.69 \\
(-0.35)\end{array}$ & $\begin{array}{l}48.16 \\
(47)\end{array}$ & $\begin{array}{l}-0.77 \\
(-1.03)\end{array}$ \\
\hline CEO tenure & $\begin{array}{l}4.32 \\
(4.50)\end{array}$ & $\begin{array}{l}3.21 \\
(3.5)\end{array}$ & $\begin{array}{l}2.32 * * \\
(2.68)^{* * *}\end{array}$ & $\begin{array}{l}3.71 \\
(3.50)\end{array}$ & $\begin{array}{l}2.63 * * \\
(2.34)^{* *}\end{array}$ \\
\hline CEO duality & $\begin{array}{l}0 \\
(0)\end{array}$ & $\begin{array}{l}0 \\
(0)\end{array}$ & $\begin{array}{l}0 \\
(0)\end{array}$ & $\begin{array}{l}0.06 \\
(0)\end{array}$ & $\begin{array}{l}-2.76 * * * \\
(0.13)\end{array}$ \\
\hline CEO education & $\begin{array}{l}17.02 \\
(16)\end{array}$ & $\begin{array}{l}16.88 \\
(16)\end{array}$ & $\begin{array}{l}0.85 \\
(0.17)\end{array}$ & $\begin{array}{l}16 \\
(16)\end{array}$ & $\begin{array}{l}1.33 \\
(0.23)\end{array}$ \\
\hline CEO pay gap & $\begin{array}{l}284259 \\
(195460)\end{array}$ & $\begin{array}{l}319660 \\
(234260)\end{array}$ & $\begin{array}{l}-0.97 \\
(-0.73)\end{array}$ & $\begin{array}{l}264825 \\
(173150)\end{array}$ & $\begin{array}{l}0.55 \\
(1.00)\end{array}$ \\
\hline $\begin{array}{l}\text { CEO political } \\
\text { connection }\end{array}$ & $\begin{array}{l}0.25 \\
(0)\end{array}$ & $\begin{array}{l}0.22 \\
(0)\end{array}$ & $\begin{array}{l}0.88 \\
(0.03)\end{array}$ & $\begin{array}{l}0.29 \\
(0)\end{array}$ & $\begin{array}{l}-0.71 \\
(0.10)\end{array}$ \\
\hline Firm size & $\begin{array}{l}7,900 \\
(3,410)\end{array}$ & $\begin{array}{l}5,300 \\
(2,400)\end{array}$ & $\begin{array}{l}1.22 \\
(1.17)\end{array}$ & $\begin{array}{l}7.020 \\
(2,980)\end{array}$ & $\begin{array}{l}1.42 \\
(2.09) * *\end{array}$ \\
\hline Leverage & $\begin{array}{l}45.87 \\
(47.39)\end{array}$ & $\begin{array}{l}49.18 \\
(48.77)\end{array}$ & $\begin{array}{l}-1.98^{*} \\
(-2.33)^{* *}\end{array}$ & $\begin{array}{l}49.09 \\
(51.88)\end{array}$ & $\begin{array}{l}-1.42 \\
(-1.22)\end{array}$ \\
\hline $\begin{array}{l}\text { Central } \\
\text { government } \\
\text { ownership }\end{array}$ & $\begin{array}{l}0.30 \\
(0)\end{array}$ & $\begin{array}{l}0.23 \\
(0)\end{array}$ & $\begin{array}{l}0.83 \\
(0.02)\end{array}$ & $\begin{array}{l}0.23 \\
(0)\end{array}$ & $\begin{array}{l}0.76 \\
(0.03)\end{array}$ \\
\hline \# of obs. & 152 & 40 & & 3,379 & \\
\hline
\end{tabular}


Panel B: CEO compensation by years

\begin{tabular}{|c|c|c|c|c|c|}
\hline & $\begin{array}{l}\text { Political } \\
\text { Promotion }\end{array}$ & $\begin{array}{l}\text { Non-political } \\
\text { promotion }\end{array}$ & $\begin{array}{l}\text { Difference test: } \\
\text { Political vs. Non- } \\
\text { political } \\
\text { promotion }\end{array}$ & $\begin{array}{l}\text { Others } \\
\text { (no turnover or } \\
\text { no promotion) }\end{array}$ & $\begin{array}{l}\text { Difference } \\
\text { test: Political } \\
\text { Promotion vs. } \\
\text { Others }\end{array}$ \\
\hline 2005 & $\begin{array}{l}300,246 \\
(189,000)\end{array}$ & $\begin{array}{l}246,078 \\
(113,400)\end{array}$ & $\begin{array}{l}1.67^{*} \\
\left(1.88^{*}\right)\end{array}$ & $\begin{array}{l}382,948 \\
(209,900)\end{array}$ & $\begin{array}{l}-1.11 \\
(-0.13)\end{array}$ \\
\hline 2006 & $\begin{array}{l}304,303 \\
(251,750)\end{array}$ & $\begin{array}{l}229,214 \\
(230,000)\end{array}$ & $\begin{array}{l}1.97 * * \\
(0.83)\end{array}$ & $\begin{array}{l}382,248 \\
(280,000)\end{array}$ & $\begin{array}{l}-1.33 \\
(-0.33)\end{array}$ \\
\hline 2007 & $\begin{array}{l}318,680 \\
(378,200)\end{array}$ & $\begin{array}{l}369,975 \\
(246,400)\end{array}$ & $\begin{array}{l}-1.03 \\
(2.07 * *)\end{array}$ & $\begin{array}{l}412,431 \\
(409,400)\end{array}$ & $\begin{array}{l}-2.56^{*} \\
(-0.43)\end{array}$ \\
\hline 2008 & $\begin{array}{l}441,436 \\
(352,450)\end{array}$ & $\begin{array}{l}493,517 \\
(309.902)\end{array}$ & $\begin{array}{l}-0.76 \\
(0.51)\end{array}$ & $\begin{array}{l}570,402 \\
(444,900)\end{array}$ & $\begin{array}{l}-2.78^{* * *} \\
(-1.87 *)\end{array}$ \\
\hline 2009 & $\begin{array}{l}403,369 \\
(385,800)\end{array}$ & $\begin{array}{l}722,644 \\
(660,443)\end{array}$ & $\begin{array}{l}-2.73^{* * *} \\
(-2.38 * *)\end{array}$ & $\begin{array}{l}513,571 \\
(468,600)\end{array}$ & $\begin{array}{l}-2.71^{* * *} \\
(-1.96 * *)\end{array}$ \\
\hline 2010 & $\begin{array}{l}478,605 \\
(340,400)\end{array}$ & $\begin{array}{l}\text { N/A } \\
\text { N/A }\end{array}$ & $\begin{array}{l}\text { N/A } \\
\text { N/A }\end{array}$ & $\begin{array}{l}610,661 \\
(436,550)\end{array}$ & $\begin{array}{l}-3.33^{* * *} \\
\left(-2.23^{* *}\right)\end{array}$ \\
\hline 2011 & $\begin{array}{l}436,055 \\
(355,617)\end{array}$ & $\begin{array}{l}668,650 \\
(609,400)\end{array}$ & $\begin{array}{l}-2.88^{* * *} \\
(-2.18 * *)\end{array}$ & $\begin{array}{l}679,266 \\
(479,500)\end{array}$ & $\begin{array}{l}-3.24^{* * *} \\
\left(-2.01^{* *}\right)\end{array}$ \\
\hline
\end{tabular}




\section{Table 3: Augmented 2SLS estimation of the effects of career concerns on compensation}

Panel A reports the results of the logistic analysis for the determinants of CEO's political promotion. The CEO political promotion is the dependent variable. The key independent variables are firm performance: ROA, ROS, Stock returns, and Tobin's $Q$ adjusted by industry average performance and observed one year before the compensation data is observed. We report the marginal effects of firm performance variables in square brackets. Firm characteristics, CEO characteristics and board characteristics are included in the controls. All explanatory variables are observed one year before the compensation observations to avoid look ahead bias. Central government turnover and central government ownership are exogenous instruments for identification, as the predicted values from the logistic regressions will be used as instruments in the later 2SLS analysis. Z-statistics (T-statistics) are in brackets, computed using robust standard errors clustered at the firm level.

Panel B presents the final stage results from the 2SLS which analyzes the relation between promotion and CEO compensation. The fitted values from the logistic analysis above are used as instruments for promotion in the $1^{\text {st }}$ stage of the 2SLS, and the predicted value are denoted as Promõtion. The results of the $2^{\text {nd }}$ stage are reported here. *, $* *$, and *** indicate significance at the $10 \%, 5 \%$, and $1 \%$ level, respectively.

\begin{tabular}{|c|c|c|c|c|}
\hline \multicolumn{5}{|c|}{ Panel A: Logistic analysis: the determinants of CEO political promotion } \\
\hline Constant & $\begin{array}{l}-1.47 \\
(-0.59)\end{array}$ & $\begin{array}{l}-0.77 \\
(-0.30)\end{array}$ & $\begin{array}{l}-4.09 * \\
(-1.74)\end{array}$ & $\begin{array}{l}-4.85^{* *} \\
(-2.00)\end{array}$ \\
\hline $\mathrm{ROA}_{\mathrm{t}-1}$ & $\begin{array}{l}1.88 * * * \\
(5.99) \\
{[0.26]}\end{array}$ & & & \\
\hline $\mathrm{ROS}_{\mathrm{t}-1}$ & & $\begin{array}{l}0.32 * * * \\
(4.40) \\
{[0.43]}\end{array}$ & & \\
\hline Stock return ${ }_{\mathrm{t}-1}$ & & & $\begin{array}{l}0.42 \\
(0.70) \\
{[0.01]}\end{array}$ & \\
\hline Tobin’s $\mathrm{Q}_{\mathrm{t}-1}$ & & & & $\begin{array}{l}0.22 * * * \\
(3.06) \\
{[0.39]}\end{array}$ \\
\hline Firm size & $\begin{array}{l}0.18^{*} \\
(1.77)\end{array}$ & $\begin{array}{l}0.20 * * \\
(1.99)\end{array}$ & $\begin{array}{l}0.32 * * * \\
(2.85)\end{array}$ & $\begin{array}{l}0.36^{* * * *} \\
(3.23)\end{array}$ \\
\hline Leverage & $\begin{array}{l}-0.75 \\
(-1.49)\end{array}$ & $\begin{array}{l}-1.56 * * * \\
(-3.60)\end{array}$ & $\begin{array}{l}-2.26 * * * \\
(-4.17)\end{array}$ & $\begin{array}{l}-2.09 * * * \\
(-4.14)\end{array}$ \\
\hline Board size & $\begin{array}{l}0.46 \\
(0.96)\end{array}$ & $\begin{array}{l}0.58 \\
(1.20)\end{array}$ & $\begin{array}{l}0.48 \\
(1.04)\end{array}$ & $\begin{array}{l}0.48 \\
(1.03)\end{array}$ \\
\hline Board independence & $\begin{array}{l}2.00 \\
(1.11)\end{array}$ & $\begin{array}{l}1.67 \\
(0.92)\end{array}$ & $\begin{array}{l}1.59 \\
(0.86)\end{array}$ & $\begin{array}{l}1.17 \\
(0.64)\end{array}$ \\
\hline CEO tenure & $\begin{array}{l}0.27 * * * \\
(5.84)\end{array}$ & $\begin{array}{l}0.31^{* * *} \\
(6.27)\end{array}$ & $\begin{array}{l}0.27 * * * \\
(4.79)\end{array}$ & $\begin{array}{l}0.26^{* * *} \\
(4.95)\end{array}$ \\
\hline CEO age & $\begin{array}{l}-0.09 * * * \\
(-4.43)\end{array}$ & $\begin{array}{l}-0.09 * * * \\
(-4.33)\end{array}$ & $\begin{array}{l}-0.09 * * * \\
(-3.79)\end{array}$ & $\begin{array}{l}-0.09 * * * \\
(-3.83)\end{array}$ \\
\hline CEO duality & $\begin{array}{l}-1.88 * * * \\
(-3.03)\end{array}$ & $\begin{array}{l}-1.79 * * * \\
(-2.90)\end{array}$ & $\begin{array}{l}-1.75 * * * \\
(-2.83)\end{array}$ & $\begin{array}{l}-1.75^{* * *} \\
(-2.77)\end{array}$ \\
\hline CEO education & $\begin{array}{l}0.11 \\
(1.34)\end{array}$ & $\begin{array}{l}0.12 \\
(1.44)\end{array}$ & $\begin{array}{l}0.09 \\
(1.01)\end{array}$ & $\begin{array}{l}0.08 \\
(0.93)\end{array}$ \\
\hline CEO pay gap & $\begin{array}{l}-2.36 * * * \\
(-4.75)\end{array}$ & $\begin{array}{l}-2.03 * * * \\
(-4.68)\end{array}$ & $\begin{array}{l}-1.84 * * * \\
(-3.43)\end{array}$ & $\begin{array}{l}-1.88 * * * \\
(-3.44)\end{array}$ \\
\hline CEO political connection & $\begin{array}{l}0.22 \\
(0.53)\end{array}$ & $\begin{array}{l}0.41 \\
(0.94)\end{array}$ & $\begin{array}{l}0.35 \\
(0.82)\end{array}$ & $\begin{array}{l}0.35 \\
(0.84)\end{array}$ \\
\hline Perquisites & $\begin{array}{l}2.07^{* * * *} \\
(4.69)\end{array}$ & $\begin{array}{l}1.64^{* * * *} \\
(4.28)\end{array}$ & $\begin{array}{l}1.57^{* * *} \\
(3.24)\end{array}$ & $\begin{array}{l}1.62 * * * \\
(3.25)\end{array}$ \\
\hline Employee & $\begin{array}{l}0.08 \\
(0.97)\end{array}$ & $\begin{array}{l}0.14 \\
(1.60)\end{array}$ & $\begin{array}{l}0.06 \\
(0.73)\end{array}$ & $\begin{array}{l}0.07 \\
(0.81)\end{array}$ \\
\hline $\begin{array}{l}\text { Central government } \\
\text { ownership }\end{array}$ & $\begin{array}{l}0.36^{*} \\
(1.65)\end{array}$ & $\begin{array}{l}0.45^{* *} \\
(2.03)\end{array}$ & $\begin{array}{l}0.30 * * \\
(2.39)\end{array}$ & $\begin{array}{l}0.27 * * \\
(2.25)\end{array}$ \\
\hline
\end{tabular}




\begin{tabular}{|c|c|c|c|c|}
\hline $\begin{array}{l}\text { Central government } \\
\text { turnover }\end{array}$ & $\begin{array}{l}0.22 * * \\
(2.26)\end{array}$ & $\begin{array}{l}0.33^{*} \\
(1.88)\end{array}$ & $\begin{array}{l}0.29 * \\
(1.65)\end{array}$ & $\begin{array}{l}0.28 * * * \\
(2.60)\end{array}$ \\
\hline Predicted Promotion & $\begin{array}{l}-3.03 * * * \\
(-2.59)\end{array}$ & $\begin{array}{l}-4.46^{*} \\
(-1.85)\end{array}$ & $\begin{array}{l}-2.48 \\
(-0.77)\end{array}$ & $\begin{array}{l}-2.69 \\
(-0.83)\end{array}$ \\
\hline Firm fixed effects & Included & Included & Included & Included \\
\hline Year fixed effects & Included & Included & Included & Included \\
\hline F-tests for instruments & 47.33 & 46.03 & 39.07 & 42.65 \\
\hline Chi-square & 84.60 & 82.73 & 99.38 & 97.55 \\
\hline Pseudo $\mathrm{R}^{2}$ & 0.34 & 0.30 & 0.29 & 0.28 \\
\hline \multicolumn{5}{|c|}{ Panel B: $2 S L S$, results of the $2^{\text {nd }}$ stage: : Dependent variable is CEO total compensation } \\
\hline Constant & $\begin{array}{l}1.02^{* *} \\
(2.09)\end{array}$ & $\begin{array}{l}0.55 \\
(1.11)\end{array}$ & $\begin{array}{l}0.51 \\
(1.03)\end{array}$ & $\begin{array}{l}0.13 \\
(0.26)\end{array}$ \\
\hline Perquisites & $\begin{array}{l}1.03^{* * * *} \\
(9.16)\end{array}$ & $\begin{array}{l}1.07 * * * \\
(9.17)\end{array}$ & $\begin{array}{l}1.07 * * * \\
(9.19)\end{array}$ & $\begin{array}{l}1.05^{* * *} \\
(9.18)\end{array}$ \\
\hline Promõtion & $\begin{array}{l}-0.29 * * \\
(-2.33)\end{array}$ & $\begin{array}{l}-0.30 * * * \\
(-3.32)\end{array}$ & $\begin{array}{l}-0.38 * * * \\
(-4.60)\end{array}$ & $\begin{array}{l}-0.40 * * * \\
(-4.74)\end{array}$ \\
\hline $\mathrm{ROA}_{\mathrm{t}-1}$ & $\begin{array}{l}2.29 * * * \\
(7.78)\end{array}$ & & & \\
\hline Promõtion * $\mathrm{ROA}_{\mathrm{t}-1}$ & $\begin{array}{l}-2.55^{* *} \\
(-2.39)\end{array}$ & & & \\
\hline $\mathrm{ROS}_{\mathrm{t}-1}$ & & $\begin{array}{l}0.05^{* * *} \\
(4.25)\end{array}$ & & \\
\hline Promõtion $* \mathrm{ROS}_{\mathrm{t}-1}$ & & $\begin{array}{l}-0.39 * * \\
(-2.00)\end{array}$ & & \\
\hline Stock return ${ }_{t-1}$ & & & $\begin{array}{l}0.03 \\
(1.26)\end{array}$ & \\
\hline Promõtion $*$ Stock return ${ }_{\mathrm{t}-1}$ & & & $\begin{array}{l}-0.12 \\
(-1.06)\end{array}$ & \\
\hline Tobin’s Q $\mathrm{t-1}$ & & & & $\begin{array}{l}0.10^{* * *} \\
(5.53)\end{array}$ \\
\hline Promõtion *Tobin's $\mathrm{Q}_{\mathrm{t}-1}$ & & & & $\begin{array}{l}-0.06 \\
(-1.09)\end{array}$ \\
\hline Firm size & $\begin{array}{l}0.20 * * * \\
(10.87)\end{array}$ & $\begin{array}{l}0.22 * * * \\
(11.52)\end{array}$ & $\begin{array}{l}0.22 * * * \\
(11.52)\end{array}$ & $\begin{array}{l}0.24 * * * \\
(12.26)\end{array}$ \\
\hline Leverage & $\begin{array}{l}-0.05 \\
(-0.63)\end{array}$ & $\begin{array}{l}-0.13^{*} \\
(-1.75)\end{array}$ & $\begin{array}{l}-0.12 \\
(-1.53)\end{array}$ & $\begin{array}{l}-0.06 \\
(-0.86)\end{array}$ \\
\hline Board size & $\begin{array}{l}-0.04 \\
(-0.49)\end{array}$ & $\begin{array}{l}-0.04 \\
(-0.47)\end{array}$ & $\begin{array}{l}-0.03 \\
(-0.39)\end{array}$ & $\begin{array}{l}-0.03 \\
(-0.34)\end{array}$ \\
\hline Board independence & $\begin{array}{l}0.48^{*} \\
(1.76)\end{array}$ & $\begin{array}{l}0.37 \\
(1.36)\end{array}$ & $\begin{array}{l}0.40 \\
(1.49)\end{array}$ & $\begin{array}{l}0.28 \\
(1.06)\end{array}$ \\
\hline CEO tenure & $\begin{array}{l}0.04 * * * \\
(7.55)\end{array}$ & $\begin{array}{l}0.04 * * * \\
(7.24)\end{array}$ & $\begin{array}{l}0.05^{* * * *} \\
(7.43)\end{array}$ & $\begin{array}{l}0.04^{* * * *} \\
(6.97)\end{array}$ \\
\hline CEO age & $\begin{array}{l}0.08^{* * * *} \\
(3.14)\end{array}$ & $\begin{array}{l}0.09 * * * \\
(3.24)\end{array}$ & $\begin{array}{l}0.09 * * * \\
(3.21)\end{array}$ & $\begin{array}{l}0.08^{* *} \\
(3.13)\end{array}$ \\
\hline CEO duality & $\begin{array}{l}0.01 \\
(0.12)\end{array}$ & $\begin{array}{l}0.01 \\
(0.26)\end{array}$ & $\begin{array}{l}0.01 \\
(0.27)\end{array}$ & $\begin{array}{l}0.01 \\
(0.14)\end{array}$ \\
\hline CEO education & $\begin{array}{l}0.02 \\
(1.12)\end{array}$ & $\begin{array}{l}0.02 \\
(1.07)\end{array}$ & $\begin{array}{l}0.02 \\
(1.10)\end{array}$ & $\begin{array}{l}0.02 \\
(0.90)\end{array}$ \\
\hline CEO pay gap & $\begin{array}{l}1.49 * * * \\
(11.27)\end{array}$ & $\begin{array}{l}1.53^{* * *} \\
(11.19)\end{array}$ & $\begin{array}{l}1.53^{* * *} \\
(11.22)\end{array}$ & $\begin{array}{l}1.51^{* * *} \\
(11.25)\end{array}$ \\
\hline CEO political connection & $\begin{array}{l}0.00 \\
(0.00)\end{array}$ & $\begin{array}{l}0.01 \\
(0.27)\end{array}$ & $\begin{array}{l}0.01 \\
(0.22)\end{array}$ & $\begin{array}{l}0.01 \\
(0.16)\end{array}$ \\
\hline Employee & $\begin{array}{l}0.04^{* * * *} \\
(2.58)\end{array}$ & $\begin{array}{l}0.04^{* * *} \\
(2.90)\end{array}$ & $\begin{array}{l}0.04 * * * \\
(2.91)\end{array}$ & $\begin{array}{l}0.04 * * * \\
(2.58)\end{array}$ \\
\hline
\end{tabular}


Firm fixed effects

Year fixed effects

Adjusted $\mathrm{R}^{2}$

\# of obs.
Included

Included

0.46

4,625
Included

Included

0.45

4,625
Included

Included

0.44

4,625
Included

Included

0.45

4,625 


\section{Table 4: Competing risk model and sub-sample estimation}

In panel A, we apply a competing risk model to analyze CEOs' competition between political promotion, and non-political promotion, or no promotion. The outcome variable (for each CEO-year) takes three discrete values: 2 for political promotion, 1 for non-political promotion, and 0 for no-promotion (no turnover or demotion), where 0 is the survival event, 2 and 1 are alternative risks (not ordered). The key explanatory variables are industry adjusted firm performance (ROA, ROS, stock market return, and Tobin's Q over the CEO's tenure). Control variables from previous equations are also included. Sub Hazard Ratio and z-values are reported in the table.

In Panel B, we analyze CEO compensation in the subsample of firms whose CEOs are promoted. The predicted value of political promotion from the first stage (where political promotion is used as dependent variable) is used as the instrumental variable for Promotion in the second stage. CEO pay is measured in logged value. ROA, ROS, Stock returns, and Tobin's $Q$ are adjusted by industry performance over the CEO's tenure. All the other variables are defined in Appendix. T-statistics are in brackets, computed using robust standard errors clustered at the firm level. *,**, and $* * *$ indicate significance at the $10 \%, 5 \%$, and $1 \%$ level, respectively.

\section{Panel A: Competition risk model}

$\mathrm{Y}(\mathrm{j}, \mathrm{t})=0$ no promotion; 1 for non-political promotion and 2 for political promotion (alternative risks).

\begin{tabular}{|c|c|c|c|c|}
\hline & (1) & (2) & (3) & (4) \\
\hline ROA & $\begin{array}{l}4.39 * * * \\
(4.74)\end{array}$ & & & \\
\hline ROS & & $\begin{array}{l}4.88^{* * *} \\
(5.21)\end{array}$ & & \\
\hline Stock return & & & $\begin{array}{l}1.11 \\
(1.27)\end{array}$ & \\
\hline Tobin’s Q & & & & $\begin{array}{l}1.20 * * * \\
(3.61)\end{array}$ \\
\hline Firm size & $\begin{array}{l}1.15^{*} \\
(1.74)\end{array}$ & $\begin{array}{l}1.15^{*} \\
(1.64)\end{array}$ & $\begin{array}{l}1.29 * * * \\
(3.13)\end{array}$ & $\begin{array}{l}1.35 * * * \\
(3.49)\end{array}$ \\
\hline Leverage & $\begin{array}{l}0.76 \\
(-0.56)\end{array}$ & $\begin{array}{l}0.31 * * * \\
(-3.08)\end{array}$ & $\begin{array}{l}0.18^{* * *} \\
(-4.92)\end{array}$ & $\begin{array}{l}0.20 * * * \\
(-4.53)\end{array}$ \\
\hline Board size & $\begin{array}{l}1.49 \\
(0.87)\end{array}$ & $\begin{array}{l}1.48^{*} \\
(0.87)\end{array}$ & $\begin{array}{l}1.40 \\
(0.79)\end{array}$ & $\begin{array}{l}1.40 \\
(0.78)\end{array}$ \\
\hline Board independence & $\begin{array}{l}4.11 \\
(1.01)\end{array}$ & $\begin{array}{l}3.38 \\
(0.68)\end{array}$ & $\begin{array}{l}3.38 \\
(0.68)\end{array}$ & $\begin{array}{l}2.17 \\
(0.44)\end{array}$ \\
\hline CEO age & $\begin{array}{l}0.85^{* * *} \\
(-3.19)\end{array}$ & $\begin{array}{l}0.85^{* * *} \\
(-3.09)\end{array}$ & $\begin{array}{l}0.85^{* * *} \\
(-3.13)\end{array}$ & $\begin{array}{l}0.85 * * * \\
(-3.25)\end{array}$ \\
\hline CEO duality & $\begin{array}{l}0.26 * * \\
(-2.36)\end{array}$ & $\begin{array}{l}0.25^{* *} \\
(-2.37)\end{array}$ & $\begin{array}{l}0.23 * * \\
(-2.54)\end{array}$ & $\begin{array}{l}0.23^{* *} \\
(-2.52)\end{array}$ \\
\hline CEO education & $\begin{array}{l}0.93 \\
(-0.82)\end{array}$ & $\begin{array}{l}0.91 \\
(-1.04)\end{array}$ & $\begin{array}{l}0.93 \\
(-0.89)\end{array}$ & $\begin{array}{l}0.93 \\
(-0.85)\end{array}$ \\
\hline CEO pay gap & $\begin{array}{l}0.25^{* * *} \\
(-5.61)\end{array}$ & $\begin{array}{l}0.30^{* * *} \\
(-4.40)\end{array}$ & $\begin{array}{l}0.30^{* * *} \\
(-4.30)\end{array}$ & $\begin{array}{l}0.28 * * * \\
(-4.66)\end{array}$ \\
\hline CEO political connection & $\begin{array}{l}0.80 \\
(-0.57)\end{array}$ & $\begin{array}{l}0.72 \\
(-0.86)\end{array}$ & $\begin{array}{l}0.73 \\
(-0.81)\end{array}$ & $\begin{array}{l}0.74 \\
(-0.79)\end{array}$ \\
\hline Perquisites & $\begin{array}{l}3.37 * * * \\
(5.23)\end{array}$ & $\begin{array}{l}2.63^{* * *} \\
(3.74)\end{array}$ & $\begin{array}{l}2.86^{* * *} \\
(3.87)\end{array}$ & $\begin{array}{l}3.06 * * * \\
(4.22)\end{array}$ \\
\hline Employee & $\begin{array}{l}1.04 \\
(0.50)\end{array}$ & $\begin{array}{l}1.13 \\
(1.40)\end{array}$ & $\begin{array}{l}1.04 \\
(0.58)\end{array}$ & $\begin{array}{l}1.05 \\
(0.63)\end{array}$ \\
\hline $\begin{array}{l}\text { Central government } \\
\text { ownership }\end{array}$ & $\begin{array}{l}1.31 \\
(1.34)\end{array}$ & $\begin{array}{l}1.37^{*} \\
(1.65)\end{array}$ & $\begin{array}{l}1.26 \\
(1.20)\end{array}$ & $\begin{array}{l}1.20 \\
(0.95)\end{array}$ \\
\hline Central government turnover & $1.38 *$ & $1.23^{* *}$ & $1.31 * *$ & $1.34 * *$ \\
\hline
\end{tabular}




\begin{tabular}{|c|c|c|c|c|}
\hline \multicolumn{2}{|c|}{$(1.79)$} & $(2.15)$ & $(2.27)$ & $(2.56)$ \\
\hline Chi-square & & 92.43 & 70.03 & 80.99 \\
\hline \# of obs. & & 4625 & 4625 & 4625 \\
\hline \multicolumn{5}{|c|}{$\begin{array}{l}\text { Panel B: Augmented 2SLS on Political promotion vs. non-political promotion, } \\
\text { Results of the } 2^{\text {nd }} \text { Stage: Dependent variable is CEO total compensation }\end{array}$} \\
\hline Constant & $\begin{array}{l}0.83 \\
(0.88)\end{array}$ & $\begin{array}{l}0.63 \\
(0.67)\end{array}$ & $\begin{array}{l}0.51 \\
(0.53)\end{array}$ & $\begin{array}{l}0.37 \\
(0.39)\end{array}$ \\
\hline Perquisites & $\begin{array}{l}0.85^{* * *} \\
(3.46)\end{array}$ & $\begin{array}{l}0.86^{* * * *} \\
(3.49)\end{array}$ & $\begin{array}{l}0.88^{* * *} \\
(3.47)\end{array}$ & $\begin{array}{l}0.87 * * * \\
(3.50)\end{array}$ \\
\hline Political Promõtion & $\begin{array}{l}-0.33 * * * \\
(-2.70)\end{array}$ & $\begin{array}{l}-0.32 * * * \\
(-3.61)\end{array}$ & $\begin{array}{l}-0.43 * * * \\
(-4.76)\end{array}$ & $\begin{array}{l}-0.45^{* * *} \\
(-5.18)\end{array}$ \\
\hline $\mathrm{ROA}_{\mathrm{t}-1}$ & $\begin{array}{l}1.93 * * * \\
(2.77)\end{array}$ & & & \\
\hline Political Promõtion $* \mathrm{ROA}_{\mathrm{t}-1}$ & $\begin{array}{l}-2.12^{* *} \\
(-1.98)\end{array}$ & & & \\
\hline $\mathrm{ROS}_{\mathrm{t}-1}$ & & $\begin{array}{l}0.38 * * * \\
(2.62)\end{array}$ & & \\
\hline Political Promõtion $* \mathrm{ROS}_{\mathrm{t}-1}$ & & $\begin{array}{l}-0.77 * * * \\
(-2.57)\end{array}$ & & \\
\hline Stock return $\mathrm{t}_{-1}$ & & & $\begin{array}{l}0.07 \\
(1.01)\end{array}$ & \\
\hline $\begin{array}{l}\text { Political Promõtion } \\
\qquad \text { *Stock return }\end{array}$ & & & $\begin{array}{l}-0.06 \\
(-0.58)\end{array}$ & \\
\hline Tobin’s $\mathrm{Q}_{\mathrm{t}-1}$ & & & & $\begin{array}{l}0.04 * * \\
(2.33)\end{array}$ \\
\hline Political Promõtion *Tobin's $\mathrm{Q}_{\mathrm{t}}$ & & & & $\begin{array}{l}-0.09 \\
(-1.03)\end{array}$ \\
\hline Firm size & $\begin{array}{l}0.24^{* * *} \\
(6.23)\end{array}$ & $\begin{array}{l}0.26 * * * \\
(6.37)\end{array}$ & $\begin{array}{l}0.26 * * * \\
(6.20)\end{array}$ & $\begin{array}{l}0.27 * * * \\
(6.18)\end{array}$ \\
\hline Leverage & $\begin{array}{l}0.27 \\
(1.56)\end{array}$ & $\begin{array}{l}0.06 \\
(0.39)\end{array}$ & $\begin{array}{l}0.09 \\
(0.49)\end{array}$ & $\begin{array}{l}0.13 \\
(0.77)\end{array}$ \\
\hline Board size & $\begin{array}{l}0.02 \\
(0.08)\end{array}$ & $\begin{array}{l}0.03 \\
(0.03)\end{array}$ & $\begin{array}{l}0.02 \\
(0.11)\end{array}$ & $\begin{array}{l}0.01 \\
(0.07)\end{array}$ \\
\hline Board independence & $\begin{array}{l}-0.61 \\
(-1.20)\end{array}$ & $\begin{array}{l}-0.75 \\
(-1.46)\end{array}$ & $\begin{array}{l}-0.71 \\
(-1.42)\end{array}$ & $\begin{array}{l}-0.71 \\
(-1.40)\end{array}$ \\
\hline CEO tenure & $\begin{array}{l}0.03^{* *} \\
(2.35)\end{array}$ & $\begin{array}{l}0.03^{* *} \\
(2.06)\end{array}$ & $\begin{array}{l}0.03 * * \\
(2.32)\end{array}$ & $\begin{array}{l}0.03^{* *} \\
(2.20)\end{array}$ \\
\hline CEO age & $\begin{array}{l}0.02^{* * *} \\
(3.13)\end{array}$ & $\begin{array}{l}0.02^{* * *} \\
(3.21)\end{array}$ & $\begin{array}{l}0.02^{* * *} \\
(3.16)\end{array}$ & $\begin{array}{l}0.02 * * \\
(3.12)\end{array}$ \\
\hline CEO duality & $\begin{array}{l}0.01 \\
(0.10)\end{array}$ & $\begin{array}{l}0.03 \\
(0.31)\end{array}$ & $\begin{array}{l}0.03 \\
(0.33)\end{array}$ & $\begin{array}{l}0.03 \\
(0.27)\end{array}$ \\
\hline CEO education & $\begin{array}{l}0.01 \\
(0.14)\end{array}$ & $\begin{array}{l}0.02 \\
(0.07)\end{array}$ & $\begin{array}{l}0.02 \\
(0.04)\end{array}$ & $\begin{array}{l}0.01 \\
(0.16)\end{array}$ \\
\hline CEO pay gap & $\begin{array}{l}1.25^{* * *} \\
(4.27)\end{array}$ & $\begin{array}{l}1.26^{* * * *} \\
(4.28)\end{array}$ & $\begin{array}{l}1.28^{* * * *} \\
(4.23)\end{array}$ & $\begin{array}{l}1.27 * * * \\
(4.28)\end{array}$ \\
\hline CEO political connection & $\begin{array}{l}0.04 \\
(0.41)\end{array}$ & $\begin{array}{l}0.03 \\
(0.30)\end{array}$ & $\begin{array}{l}0.03 \\
(0.28)\end{array}$ & $\begin{array}{l}0.04 \\
(0.45)\end{array}$ \\
\hline Employee & $\begin{array}{l}0.04 \\
(1.49)\end{array}$ & $\begin{array}{l}0.04 \\
(1.47)\end{array}$ & $\begin{array}{l}0.05^{*} \\
(1.73)\end{array}$ & $\begin{array}{l}0.05 \\
(1.57)\end{array}$ \\
\hline Firm fixed effects & Included & Included & Included & Included \\
\hline Year fixed effects & Included & Included & Included & Included \\
\hline Adjusted $\mathrm{R}^{2}$ & 0.42 & 0.42 & 0.41 & 0.42 \\
\hline \# of obs. & 692 & 692 & 692 & 692 \\
\hline
\end{tabular}




\section{Table 5: Univariate tests of firm performance around CEO assignments and turnover}

The table reports the change in firm performance around CEO appointments and departures. $t$ indicates the year when the CEO is appointed, and T indicates the year when the CEO departs from the position. The sample includes all firms with a CEO departure during the 2005 to 2011 period, and their performance may be traced back beyond 2005. Performance is measured using industry-adjusted ROA and ROS. If the promotion occurred in the first (second) half of the year, we use the prior (current) year's firm performance (Huson et al., 2001; Chang and Wong, 2009). Crosssectional mean (median) values are reported for the different groups by event year, as well as t-statistics and Wilcoxon values of the difference between CEO groups.

\begin{tabular}{|c|c|c|c|c|c|}
\hline & $\begin{array}{l}\text { Political } \\
\text { Promotion }\end{array}$ & $\begin{array}{l}\text { Non-political } \\
\text { Promotion }\end{array}$ & $\begin{array}{l}\text { Difference test: } \\
\text { Political } \\
\text { promotion vs. } \\
\text { Other promotion }\end{array}$ & $\begin{array}{l}\text { Others } \\
\text { (No turnover or } \\
\text { no promotion) }\end{array}$ & $\begin{array}{l}\text { Difference test: } \\
\text { Political Promotion } \\
\text { vs. others }\end{array}$ \\
\hline \multicolumn{6}{|c|}{ Panel A: Firm performance measured by ROA (\%) } \\
\hline $\mathrm{t}-1$ & $\begin{array}{l}2.52 \\
(2.13)\end{array}$ & $\begin{array}{l}2.65 \\
(2.69)\end{array}$ & $\begin{array}{l}-0.32 \\
(-0.72)\end{array}$ & $\begin{array}{l}2.13 \\
(2.05)\end{array}$ & $\begin{array}{l}0.73 \\
(0.08)\end{array}$ \\
\hline $\mathrm{t}$ & $\begin{array}{l}3.55 \\
(3.71)\end{array}$ & $\begin{array}{l}2.14 \\
(2.88)\end{array}$ & $\begin{array}{l}1.07 \\
(0.62)\end{array}$ & $\begin{array}{l}2.03 \\
(2.52)\end{array}$ & $\begin{array}{l}1.60 \\
(1.35)\end{array}$ \\
\hline$t+1$ & $\begin{array}{l}4.41 \\
(3.78)\end{array}$ & $\begin{array}{l}3.99 \\
(3.33)\end{array}$ & $\begin{array}{l}0.68 \\
(0.55)\end{array}$ & $\begin{array}{l}1.44 \\
(1.77)\end{array}$ & $\begin{array}{l}2.66 * * * \\
(2.13)^{* *}\end{array}$ \\
\hline $\mathrm{T}-1$ & $\begin{array}{l}6.05 \\
(5.11)\end{array}$ & $\begin{array}{l}3.56 \\
(3.15)\end{array}$ & $\begin{array}{l}2.76 * * * \\
(2.20)^{* *}\end{array}$ & $\begin{array}{l}1.92 \\
(2.37)\end{array}$ & $\begin{array}{l}3.30 * * * \\
(3.01)^{* * *}\end{array}$ \\
\hline $\mathrm{T}$ & $\begin{array}{l}6.45 \\
(5.41)\end{array}$ & $\begin{array}{l}4.57 \\
(3.82)\end{array}$ & $\begin{array}{l}2.33^{* *} \\
(1.99)^{* *}\end{array}$ & $\begin{array}{l}1.55 \\
(2.15)\end{array}$ & $\begin{array}{l}5.27 * * * \\
(4.08) * * *\end{array}$ \\
\hline
\end{tabular}

Panel B: Firm performance measured by ROS (\%)

\begin{tabular}{llllll}
\hline $\mathrm{t}-1$ & 3.41 & 3.98 & -0.72 & 2.41 & 1.17 \\
& $(3.88)$ & $(4.16)$ & $(-0.38)$ & $(2.28)$ & $(1.45)$ \\
$\mathrm{t}$ & 3.30 & 3.90 & 0.64 & 2.40 & 1.62 \\
& $(3.60)$ & $(3.24)$ & $(1.84)^{*}$ & $(2.24)$ & $(1.76)^{*}$ \\
$\mathrm{t}+1$ & 6.60 & 4.58 & $2.08^{* *}$ & 2.86 & $2.64^{* * *}$ \\
& $(5.16)$ & $(4.70)$ & $(0.78)$ & $(2.16)$ & $(2.33)^{* *}$ \\
$\mathrm{~T}-1$ & 8.27 & 7.89 & 0.87 & 2.42 & $3.68^{* * *}$ \\
& $(6.12)$ & $(5.30)$ & $(1.03)$ & $(2.18)$ & $(3.22)^{* * *}$ \\
$\mathrm{~T}$ & 10.75 & 10.42 & 1.04 & 2.77 & $4.69^{* * *}$ \\
& $(8.67)$ & $(8.75)$ & $(-0.08)$ & $(3.36)$ & $(3.87)^{* * *}$ \\
\hline
\end{tabular}

Panel C: Firm performance measured by stock return (\%)

\begin{tabular}{llllll}
\hline $\mathrm{t}-1$ & 8.97 & 0.18 & 1.41 & 7.35 & 0.88 \\
& $(14.34)$ & $(10.71)$ & $(0.56)$ & $(4.24)$ & $(1.33)$
\end{tabular}




\begin{tabular}{llllll}
$\mathrm{t}$ & 70.71 & 70.14 & 0.19 & 70.86 & -0.18 \\
& $(80.79)$ & $(81.63)$ & $(-0.11)$ & $(81.22)$ & $(-0.22)$ \\
$\mathrm{t}+1$ & 29.79 & 44.39 & $-1.81^{*}$ & 68.33 & $-2.01^{* *}$ \\
& $(68.79)$ & $(49.25)$ & $(1.64)^{*}$ & $(68.80)$ & $(-0.01)$ \\
$\mathrm{T}-1$ & 39.10 & 40.65 & -0.17 & 60.30 & $-1.91^{*}$ \\
& $(11.76)$ & $(34.36)$ & $(-0.43)$ & $(62.12)$ & $(-1.98)^{* *}$ \\
$\mathrm{~T}$ & 48.27 & 49.02 & -1.00 & 45.49 & 0.37 \\
& $(-1.62)$ & $(20.14)$ & $(-1.12)$ & $(7.74)$ & $(-0.85)$ \\
\hline \multirow{2}{*}{ Panel D: Firm performance measured by Tobin's Q } & & & \\
& & & & & \\
\hline $\mathrm{t}-1$ & 1.06 & 1.09 & -0.01 & 1.06 & 0.01 \\
& $(0.99)$ & $(1.02)$ & $(-0.06)$ & $(0.99)$ & $(0.00)$ \\
$\mathrm{t}$ & 1.37 & 1.34 & 0.13 & 1.36 & 0.08 \\
& $(1.15)$ & $(1.18)$ & $(-0.05)$ & $(1.17)$ & $(-0.09)$ \\
$\mathrm{t}+1$ & 1.65 & 1.29 & 1.45 & 1.11 & $1.68^{*}$ \\
& $(1.20)$ & $(1.27)$ & $(-0.76)$ & $(1.31)$ & $(-1.03)$ \\
$\mathrm{T}-1$ & 1.66 & 1.16 & 1.56 & 1.16 & 1.63 \\
& $(1.22)$ & $(1.27)$ & $(-0.15)$ & $(1.71)$ & $(-1.89)^{*}$ \\
$\mathrm{~T}$ & 1.73 & 1.41 & 1.25 & 1.62 & 0.26 \\
& $(1.29)$ & $(1.37)$ & $(-0.26)$ & $(1.31)$ & $(-0.13)$ \\
\hline
\end{tabular}


Table 6: Difference tests of firm performance within different promotion categories

This table compares the change in firm performance over time within the three promotion groups (political promotion, non-political promotion, and no promotion). $t$ indicates the year when the CEO is appointed, and T indicates the year when the CEO departs from the position.

\begin{tabular}{lllllll}
\hline \multicolumn{2}{c}{$\mathrm{t}-1$} & $\mathrm{t}$ & $\mathrm{T}$ & $\begin{array}{l}\text { Difference test } \\
\mathrm{T} \text { and } \mathrm{t}-1\end{array}$ & $\begin{array}{l}\text { Difference test } \\
\mathrm{T} \text { and } \mathrm{t}\end{array}$ & $\begin{array}{l}\text { Difference test } \\
\text { Tenure Average } \\
\text { and t-1 }\end{array}$ \\
\hline \multicolumn{7}{l}{ Panel A: Difference tests within political promotion } \\
\hline ROA (\%) & 2.52 & 3.55 & 6.45 & $4.45^{* * *}$ & $3.46^{* * *}$ & $2.33^{* *}$ \\
& $(2.13)$ & $(3.71)$ & $(5.41)$ & $(6.33)^{* * *}$ & $(5.21)^{* * *}$ & $(2.79)^{* * *}$ \\
ROS (\%) & 3.41 & 3.30 & 10.75 & $3.79^{* * *}$ & $3.09^{* * *}$ & $2.77^{* * *}$ \\
& $(3.88)$ & $(3.60)$ & $(8.67)$ & $(3.01)^{* * *}$ & $(2.98)^{* * *}$ & $(2.55)^{* *}$ \\
Stock market & 8.97 & 70.71 & 48.27 & 1.52 & -1.17 & $1.71^{*}$ \\
returns (\%) & $(14.34)$ & $(80.79)$ & $(-1.62)$ & $(-0.98)$ & $(-1.48)$ & $(0.84)$ \\
Tobin's Q & 1.06 & 1.37 & 1.73 & $2.11^{* *}$ & 1.38 & $1.81^{*}$ \\
& $(0.99)$ & $(1.15)$ & $(1.29)$ & $(1.35)$ & $(0.40)$ & $(1.29)$ \\
\hline
\end{tabular}

Panel B: Difference tests within non-political promotion group

\begin{tabular}{|c|c|c|c|c|c|c|}
\hline ROA (\%) & $\begin{array}{l}2.65 \\
(2.69)\end{array}$ & $\begin{array}{l}2.14 \\
(2.88)\end{array}$ & $\begin{array}{l}4.57 \\
(3.82)\end{array}$ & $\begin{array}{l}2.46^{* *} \\
(1.86)^{*}\end{array}$ & $\begin{array}{l}2.79 * * * \\
(1.78) *\end{array}$ & $\begin{array}{l}2.45 * * \\
(1.84)^{*}\end{array}$ \\
\hline ROS (\%) & $\begin{array}{l}3.98 \\
(4.16)\end{array}$ & $\begin{array}{l}3.90 \\
(3.24)\end{array}$ & $\begin{array}{l}10.42 \\
(8.75)\end{array}$ & $\begin{array}{l}4.40 * * * \\
(2.88)^{* * *}\end{array}$ & $\begin{array}{l}4.90 * * * \\
(3.67)^{* * *}\end{array}$ & $\begin{array}{l}4.78 * * * \\
(2.79)^{* * *}\end{array}$ \\
\hline $\begin{array}{l}\text { Stock market } \\
\text { returns (\%) }\end{array}$ & $\begin{array}{l}0.18 \\
(10.71)\end{array}$ & $\begin{array}{l}70.14 \\
(81.63)\end{array}$ & $\begin{array}{l}49.02 \\
(20.14)\end{array}$ & $\begin{array}{l}1.30 \\
(0.70)\end{array}$ & $\begin{array}{l}-0.70 \\
(-1.00)\end{array}$ & $\begin{array}{l}1.73^{*} \\
(1.31)\end{array}$ \\
\hline Tobin’s Q & $\begin{array}{l}1.09 \\
(1.02)\end{array}$ & $\begin{array}{l}1.34 \\
(1.18)\end{array}$ & $\begin{array}{l}1.41 \\
(1.37)\end{array}$ & $\begin{array}{l}1.45 \\
(1.18)\end{array}$ & $\begin{array}{l}0.36 \\
(0.97)\end{array}$ & $\begin{array}{l}1.29 \\
(1.01)\end{array}$ \\
\hline
\end{tabular}

Panel C: Difference tests within other group (no turnover, normal turnover, or demotion)

\begin{tabular}{lllllll}
\hline ROA (\%) & 2.13 & 2.03 & 1.55 & 0.37 & 0.40 & 0.10 \\
& $(2.05)$ & $(2.52)$ & $(2.15)$ & $(0.17)$ & $(0.68)$ & $(-0.16)$ \\
ROS (\%) & 2.41 & 2.40 & 2.77 & 0.79 & 0.95 & 0.75 \\
& $(2.28)$ & $(2.24)$ & $(3.36)$ & $(1.33)$ & $(1.40)$ & $(1.26)$ \\
Stock market & 7.35 & 70.86 & 45.49 & $1.89 *$ & -1.19 & $2.34^{* *}$ \\
returns (\%) & $(4.24)$ & $(81.22)$ & $(7.74)$ & $(1.31)$ & $(-1.60)$ & $(1.93)^{*}$ \\
Tobin's Q & 1.06 & 1.36 & 1.62 & $2.02^{* *}$ & 1.52 & $1.64^{*}$ \\
& $(0.99)$ & $(1.17)$ & $(1.31)$ & $(1.55)$ & $(1.24)$ & $(1.40)$ \\
\hline
\end{tabular}




\section{Table 7: Compensation of successors}

This table presents results on the compensation of those CEOs whose predecessors are politically promoted. We first predict the likelihood of each successor being politically promoted in the future. We then explain their compensation using the variables in Table 5 and the indicator Low Promotion for those successors whose predicted likelihood is lower than average (median).

\begin{tabular}{|c|c|c|c|c|}
\hline \multicolumn{5}{|c|}{ Dependent variable is CEO total compensation } \\
\hline \multirow[t]{2}{*}{ Constant } & 0.77 & 0.41 & 1.05 & 0.34 \\
\hline & $(0.47)$ & $(0.26)$ & $(0.66)$ & $(0.22)$ \\
\hline \multirow[t]{2}{*}{ Perquisites } & $0.68 * *$ & $0.69 * *$ & $0.67 * *$ & $0.68 * * *$ \\
\hline & $(2.53)$ & $(2.51)$ & $(2.52)$ & $(2.57)$ \\
\hline \multirow[t]{2}{*}{ ROA } & $0.80 *$ & & & \\
\hline & (1.93) & & & \\
\hline \multirow[t]{2}{*}{ Low Promotion *ROA } & $0.90 *$ & & & \\
\hline & $(1.81)$ & & & \\
\hline \multirow[t]{2}{*}{ ROS } & & $0.04 * *$ & & \\
\hline & & $(2.06)$ & & \\
\hline \multirow[t]{2}{*}{ Low Promotion*ROS } & & $0.51 * *$ & & \\
\hline & & $(2.33)$ & & \\
\hline \multirow[t]{2}{*}{ Stock return } & & & -0.03 & \\
\hline & & & $(-1.18)$ & \\
\hline \multirow[t]{2}{*}{ Low Promotion*Stock return } & & & -0.06 & \\
\hline & & & $(-1.09)$ & \\
\hline \multirow[t]{2}{*}{ Tobin’s Q } & & & & $0.08 * * *$ \\
\hline & & & & $(2.73)$ \\
\hline \multirow[t]{2}{*}{ Low Promotion* Tobin’s Q } & & & & $0.08 *$ \\
\hline & & & & $(1.64)$ \\
\hline \multirow[t]{2}{*}{ Low Promotion } & $0.17 * *$ & $0.15^{* *}$ & $0.14 * *$ & $0.25 * *$ \\
\hline & $(2.13)$ & $(2.07)$ & $(2.04)$ & $(2.56)$ \\
\hline \multirow[t]{2}{*}{ Firm size } & $0.24 * * *$ & $0.25 * * *$ & $0.23 * * *$ & $0.26 * * *$ \\
\hline & $(4.42)$ & $(4.80)$ & $(4.36)$ & $(4.73)$ \\
\hline \multirow[t]{2}{*}{ Leverage } & 0.08 & 0.04 & 0.04 & 0.06 \\
\hline & $(0.29)$ & $(0.13)$ & $(0.14)$ & $(0.22)$ \\
\hline \multirow[t]{2}{*}{ Board size } & 0.09 & 0.09 & 0.11 & 0.09 \\
\hline & $(0.46)$ & $(0.50)$ & $(0.59)$ & $(0.48)$ \\
\hline \multirow[t]{2}{*}{ Board independence } & -0.53 & -0.62 & -0.59 & -0.58 \\
\hline & $(-0.66)$ & $(-0.82)$ & $(-0.74)$ & $(-0.73)$ \\
\hline \multirow[t]{2}{*}{ CEO tenure } & 0.03 & 0.03 & 0.03 & 0.04 \\
\hline & $(1.55)$ & $(1.26)$ & $(1.51)$ & $(1.56)$ \\
\hline \multirow[t]{2}{*}{ CEO age } & $0.02 * *$ & $0.02 * *$ & $0.02 * *$ & $0.02 * * *$ \\
\hline & $(2.55)$ & $(2.53)$ & $(2.46)$ & $(2.58)$ \\
\hline \multirow[t]{2}{*}{ CEO duality } & -0.25 & -0.24 & -0.23 & -0.26 \\
\hline & $(-1.07)$ & $(-1.00)$ & $(-0.96)$ & $(-1.15)$ \\
\hline \multirow[t]{2}{*}{ CEO education } & 0.04 & 0.04 & 0.03 & 0.03 \\
\hline & $(0.09)$ & $(0.08)$ & $(0.09)$ & $(0.03)$ \\
\hline \multirow[t]{2}{*}{ CEO pay gap } & $1.07 * * *$ & $1.09 * * *$ & $1.06 * * *$ & $1.06 * * *$ \\
\hline & $(3.24)$ & (3.23) & $(3.20)$ & $(3.26)$ \\
\hline \multirow[t]{2}{*}{ CEO political connection } & 0.35 & 0.37 & 0.37 & 0.34 \\
\hline & (1.49) & (1.61) & $(1.57)$ & $(1.51)$ \\
\hline Employee & 0.05 & $0.06 *$ & 0.05 & $0.06 *$ \\
\hline & $(1.45)$ & $(1.87)$ & $(1.39)$ & $(1.67)$ \\
\hline Firm fixed effects & Included & Included & Included & Included \\
\hline Year fixed effects & Included & Included & Included & Included \\
\hline Adjusted $\mathrm{R}^{2}$ & 0.46 & 0.47 & 0.46 & 0.46 \\
\hline \# of obs. & 872 & 872 & 872 & 872 \\
\hline
\end{tabular}


